\title{
Effects of Prenatal Nicotine Exposure on Primate Brain Development and Attempted Amelioration with Supplemental Choline or Vitamin C: Neurotransmitter Receptors, Cell Signaling and Cell Development Biomarkers in Fetal Brain Regions of Rhesus Monkeys
}

\author{
Theodore A Slotkin*,', Frederic J Seidler', Dan Qiao', Justin E Aldridge', Charlotte A Tate', \\ Mandy M Cousins', Becky J Proskocil' ${ }^{2}$, Harmanjatinder S Sekhon ${ }^{2}$, Jennifer A Clark ${ }^{2}$, \\ Stacie L Lupo ${ }^{2}$ and Eliot R Spindel ${ }^{2}$ \\ 'Department of Pharmacology and Cancer Biology, Duke University Medical Center, Durham, NC, USA; ${ }^{2}$ Division of Neuroscience, Oregon \\ National Primate Research Center, Oregon Health and Science University, Beaverton, OR, USA
}

\begin{abstract}
Studies in developing rodents indicate that nicotine is a neuroteratogen that disrupts brain development by stimulating nicotinic acetylcholine receptors ( $\mathrm{nAChRs)}$ that control neural cell replication and differentiation. We administered nicotine to pregnant Rhesus monkeys from gestational day 30 through 160 by continuous infusion, achieving maternal plasma levels comparable to those in smokers $(30 \mathrm{ng} / \mathrm{ml})$. Fetal brain regions and peripheral tissues were examined for nAChR subtypes, other neurotransmitter receptors, and indices of cell signaling and cell damage. Nicotine evoked nAChR upregulation, but with distinct regional disparities indicative of selective stimulatory responses. Similarly, indices of cell loss (reduced DNA), cell size and neuritic outgrowth (protein/DNA and membrane/total protein ratios) were distinct for each region and did not necessarily follow the rank order of nAChR upregulation, suggesting the involvement of additional mechanisms such as oxidative stress. We then attempted to offset the adverse effects of nicotine with standard dietary supplements known to interact with nicotine. By itself, choline elicited nicotine-like actions commensurate with its promotion of cholinergic neurotransmission. When given in combination with nicotine, choline protected some regions from damage but worsened nicotine's effects in other regions. Similarly, Vitamin C supplementation had mixed effects, increasing nAChR responses while providing protection from cell damage in the caudate, the brain region most susceptible to oxidative stress. Our results indicate that nicotine elicits neurodevelopmental damage that is highly selective for different brain regions, and that dietary supplements ordinarily thought to be neuroprotectant may actually worsen some of the adverse effects of nicotine on the fetal brain.

Neuropsychopharmacology (2005) 30, 129-144, advance online publication, 18 August 2004; doi: I 0. I038/sj.npp. 1300544
\end{abstract}

Keywords: adenylyl cyclase; $\beta$-adrenoceptor; choline supplementation; fetal brain development; muscarinic cholinergic receptor; nicotine; nicotinic cholinergic receptor; vitamin $C$ supplementation

\section{INTRODUCTION}

Maternal smoking during pregnancy accounts for thousands of perinatal and neonatal deaths in the US each year, along with a wide spectrum of neurodevelopmental disorders as the offspring progress through childhood and adolescence (DiFranza and Lew, 1995; Ernst et al, 2001;

*Correspondence: Dr TA Slotkin, Duke University Medical Center, Box 3813 DUMC, Durham, NC 277I0, USA, Tel: +919 68I 80I5, Fax: + 919684 8197, E-mail: t.slotkin@duke.edu

Received 6 May 2004; revised I July 2004; accepted 19 July 2004 Online publication: 26 July 2004 at http://www.acnp.org/citations/ Npp07260404217/default.pdf
Frank et al, 2001; Wakschlag et al, 2002; Weitzman et al, 2002). Animal models, chiefly in rodents, have shown that nicotine is a neuroteratogen that targets neural replication and differentiation, synaptic development and synaptic activity, culminating in functional deficits and cognitive impairment that parallel the findings in offspring of smokers (Levin and Slotkin, 1998; Slotkin, 1992, 1999, 2004). Thus, although tobacco smoke contains thousands of bioactive compounds, nicotine by itself contributes significantly to fetal brain damage and its functional consequences, a factor that must be taken into account in smoking cessation strategies that utilize nicotine replacement therapy (Benowitz et al, 2000). Nicotine affects brain development because it stimulates nicotinic acetylcholine 
receptors (nAChRs); in the immature brain, acetylcholine, among other neurotransmitters, plays a critical neurotrophic role in determining the patterns of cell development (Lauder and Schambra, 1999; Weiss et al, 1998). Essentially, by providing excessive cholinergic stimulation throughout fetal life, nicotine discoordinates the numerous events in cell replication, differentiation and synaptic development that are necessary to the proper assembly of the mammalian brain.

Nevertheless, there are key questions about the developmental neurotoxicity of nicotine for which models based on rats or mice are particularly problematic. First, because these species are altricial, birth occurs at neurodevelopmental stages analogous to the end of the second trimester of human pregnancy, so that adverse effects originating in late gestation would be better modeled in nonhuman primates such as the monkey. Second, the larger amounts of tissue available from fetal monkey brain enables determinations to be carried out more readily in specified regions and subregions. Third, and most obviously, brain development in primates more closely mimics the same processes in human brain development. To our knowledge, however, only scant information is available in primates concerning the effects of nicotine on neurodevelopment, limited to examination of nAChRs in the lung and with environmental tobacco smoke exposure (rather than just nicotine) in one broadly defined brain region (Sekhon et al, 1999; Slotkin et al, 2002). In contrast, there is far more information on the developmental neurotoxicity of cocaine in monkeys, information that has given a much more comprehensive view of mechanisms and consequences of exposure to that drug of abuse (Choi and Ronnekleiv, 1996; Fang and Ronnekleiv, 1999; Lidow and Song, 2001).

In the current study, we administered nicotine to pregnant Rhesus macaque monkeys throughout pregnancy until just before term, using continuous infusions of nicotine via osmotic minipumps, so as to avoid confounding effects of fluctuating drug levels and the associated incidence of fetal hypoxia/ischemia (Levin and Slotkin, 1998; Slotkin, 1992, 1999, 2004), carefully matching the dose rate so as to simulate the plasma levels of nicotine commonly associated with maternal smoking or with use of transdermal nicotine patches (Benowitz et al, 1990; Fredrickson et al, 1995; Isaac and Rand, 1972; Lichtensteiger et al, 1988; Luck et al, 1985; Murrin et al, 1987). Fetal brain regions, heart and lung were then examined for four families of biomarkers known to characterize neurodevelopmental deficits associated with nicotine exposure. First, we assessed radioligand binding to two nAChR subtypes that play defined roles in neural development, $\alpha 4 \beta 2$ and $\alpha 7$. The $\alpha 4 \beta 2 \mathrm{nAChR}$ is the most abundant form in the mammalian brain (Flores et al, 1992; Happe et al, 1994; Whiting and Lindstrom, 1987; Whiting and Lindstrom, 1988) and its upregulation by nicotine in the fetus is mechanistically involved in the adverse effects of nicotine on cell development, as well as providing a biomarker for neural cell stimulation by nicotine (Levin and Slotkin, 1998; Slotkin, 1992, 1999, 2004). Although present in lower concentrations, the $\alpha 7 \mathrm{nAChR}$ is closely associated with the response to brain injury (Verbois et al, 2002) and with the effects of nicotine on neuritic outgrowth (Chan and Quik, 1993; Quik et al, 1994). Second, we focused on the effects on neurotransmitter receptors and cell signaling proteins that control the generation of the second messenger, cyclic AMP. In the developing brain, cyclic AMP plays a key role in the coordination of cell replication and differentiation, synaptic outgrowth, and apoptosis (Shaywitz and Greenberg, 1999; Stachowiak et al, 2003) and is a common site for disruption of brain development by neuroteratogens (Levitt et al, 1997; Slotkin et al, 2003a; Whitaker-Azmitia, 1991; Yanai et al, 2002). We performed a battery of tests designed to evaluate the impact of fetal nicotine exposure on the signaling cascade converging on adenylyl cyclase (AC) the enzyme that generates cyclic AMP (Figure 1). First, we assessed radioligand binding to two receptors that exert opposing actions on AC: $\beta$-adrenoceptors ( $\beta \mathrm{ARs}$ ), which stimulate the enzyme through participation of the stimulatory G-protein $\left(\mathrm{G}_{\mathrm{s}}\right)$, and type 2 muscarinic cholinergic receptors ( $\mathrm{m}_{2} \mathrm{AChRs}$ ), which suppress AC activity through the inhibitory G-protein $\left(G_{i}\right)$. We then tested the ability of $\beta \mathrm{AR}$ and $\mathrm{m}_{2} \mathrm{AChR}$ receptor stimulants to affect AC activity, and contrasted the effects with alterations in basal AC activity or in the response of AC to direct stimulants (forskolin, $\mathrm{Mn}^{2+}$ ) that bypass the need for receptor activation. Forskolin and $\mathrm{Mn}^{2+}$ act at different epitopes on the AC molecule, so the preference for one over the other reflects shifts in molecular conformation, primarily influenced by the AC isoform (Zeiders et al, 1999b). Effects mediated at the level of AC are 'heterologous,' that is, they influence the cellular response to multiple neurotransmitter and hormonal inputs that converge on cyclic AMP as a second messenger (Slotkin et al, 2003a).

The third battery of measurements focused on more general indices of cell development that have been shown to detect nicotine-induced neural cell injury (Levin and Slotkin, 1998; Slotkin, 1992, 1999, 2004). As each neural cell contains only a single nucleus (Winick and Noble, 1965), the DNA concentration reflects the cell packing density (Bell et al, 1987; Slotkin et al, 1984; Winick and Noble, 1965). We also assessed the complement of cell

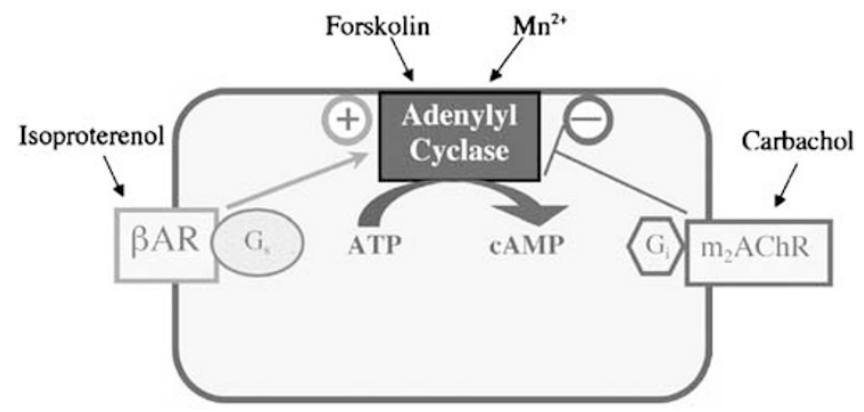

Figure I Stimulatory and inhibitory inputs controlling adenylyl cyclase (AC) activity. $\beta$-Adrenoceptors ( $\beta$ ARs) enhance AC activity through the stimulatory $\mathrm{G}$-protein, $\mathrm{G}_{\mathrm{s}}$, whereas type 2 muscarinic cholinergic receptors $\left(m_{2} A C h R s\right)$ diminish $A C$ activity through the inhibitory protein, $G_{j}$. Each step in the pathway can be probed with the appropriate stimulant: isoproterenol for $\beta A R s$, carbachol for the $\mathrm{m}_{2} \mathrm{AChR}$, and forskolin or $\mathrm{Mn}^{2+}$ for $A C$ itself. The attachment of $G_{s}$ to $A C$ enhances the response to forskolin while suppressing the response to $\mathrm{Mn}^{2+}$ and in addition, different $\mathrm{AC}$ isoforms show preferential responses to forskolin vs $\mathrm{Mn}^{2+}$. When alterations involve signaling elements downstream from the receptors $\left(G_{s}\right.$ AC), effects will be shared by multiple receptors, and will therefore be 'heterologous.' 
proteins related to differentiation as opposed to cell numbers. As neurons specialize, they enlarge and develop axonal and dendritic projections. The ratio of total protein/ DNA thus rises with the expansion of the cell (Bell et al, 1987; Slotkin et al, 1984). In cells that do not develop projections, the membrane surface-to-volume ratio falls as the cell enlarges, so that the membrane protein concentration falls with hypertrophy (Thai et al, 1996); however, for neural cells, the development of neuritic projections necessitates a rise in the contribution of membrane proteins relative to other cell proteins. Accordingly, we also assessed the ratio of membrane protein to total cell protein. As measurements of DNA and protein subfractions integrate values across different cell types (neurons, glia) and across different subregions, the magnitude of changes induced by neurotoxicants tends to be small; that is, a robust effect on a specific neuron population is diluted with unaffected components. However, as these values are tightly controlled, even small differences are readily detectable (Bell et al, 1987; Qiao et al, 2002, 2003, 2004; Slotkin et al, 1984; Winick and Noble, 1965).

Finally, in light of the fact that nicotine may induce oxidative stress, we assayed thiobarbituric acid-reactive species (TBARS) in brain regions, peripheral tissues, and the placenta. Lipid peroxidation, one of the main endpoints of oxidative stress, generates malondialdehyde, which is then readily detected with the TBARS assay (Guan et al, 2003).

In addition to evaluating the effects of fetal nicotine exposure, we also assessed the potential amelioration of nicotine's effects with choline or Vitamin C. In a number of brain regions, perinatal dietary choline supplementation has been found to increase synaptic plasticity and performance, including protection from neurotoxicants like ethanol (Meck and Williams, 1999; Montoya et al, 2000; Thomas et al, 2000; Williams et al, 1998). At the same time, earlier work with lecithin dietary supplements suggested that other regions might show adverse developmental effects closely resembling those of nicotine (Bell and Lundberg, 1985; Bell and Slotkin, 1985; Bell et al, 1986a, b; Levin and Slotkin, 1998; Slotkin, 1992, 1999, 2004). In fact, choline supplementation enhances acetylcholine synthesis and release (Wurtman, 1988), and choline acts as an agonist at the $\alpha 7 \mathrm{nAChR}$ (Mike et al, 2000), thus potentially producing additive or synergistic effects with nicotine. Accordingly, we evaluated the effects of dietary choline supplementation, alone or in combination with nicotine exposure, on fetal brain development. Similarly, we evaluated whether the antioxidant properties of Vitamin $\mathrm{C}$ might be effective in preventing those aspects of nicotine's developmental neurotoxicity that are potentially related to oxidative stress (Guan et al, 2003).

\section{MATERIALS AND METHODS}

\section{Animal Treatments and Tissue Dissections}

All studies were carried out with the approval of the Oregon National Primate Research Center's Institutional Animal Care and Use Committee, in accordance with the declaration of Helsinki and with the Guide for the Care and Use of Laboratory Animals as adopted and promulgated by the
National Institutes of Health. In total, 34 pregnant Rhesus macaque monkeys were divided into five treatment groups that received treatments beginning on day 30 of pregnancy, continuing through day 160: six controls, and seven each in groups receiving nicotine, choline supplementation, nicotine + choline, or nicotine + Vitamin C supplementation. Nicotine was delivered by continuous infusion using subcutaneously implanted osmotic minipumps with a 4week capacity (Alzet type 2ML4) containing nicotine bitartrate dissolved in bacteriostatic water, set to deliver $2 \mathrm{mg} / \mathrm{kg} /$ day (equivalent to $0.7 \mathrm{mg} / \mathrm{kg} /$ day of nicotine-free base), whereas groups not receiving nicotine (control, choline) had pumps containing only bacteriostatic water. Pumps were implanted under ketamine anesthesia and were changed every 3 weeks to maintain a steady-state infusion throughout pregnancy; minipump changes were carried out under the direction of a veterinary surgeon following strict sterile protocols. Choline supplementation was supplied by inclusion of choline in apple juice so as to raise the intake five-fold above the normal dietary level, with controls receiving approximately $3 \mathrm{mmol} /$ day and drinking unsupplemented apple juice, whereas the supplemented groups received $15 \mathrm{mmol} /$ day. Ascorbic acid supplementation was delivered orally at a daily $250 \mathrm{mg}$ dose in the form of a chewable vitamin pill.

On the 160th day of pregnancy, animals were anesthetized with ketamine and isoflurane and the fetuses delivered by Caesarean section as described previously (Sekhon et al, 2001). Samples of maternal blood and amniotic fluid were analyzed for nicotine and cotinine in the laboratory of Dr Neal Benowitz (University of California, San Francisco), using gas chromatography with nitrogen-phosphorus detection (Jacob et al, 1981), modified for simultaneous extraction of nicotine and cotinine (Jacob et al, 1991). The limit of quantitation was $1 \mathrm{ng} / \mathrm{ml}$ for nicotine and $10 \mathrm{ng} / \mathrm{ml}$ for cotinine. Internal standards, 5-methylnicotine and ortho-cotinine, were obtained from Dr Peyton Jacob III (University of California, San Francisco).

A section of the placenta from the periphery of the placental disc was dissected and frozen with liquid nitrogen. Similarly, the fetal cardiac lobe of the left lung and a section across the fetal left and right ventricle were taken from the heart, being careful to use exactly the same location in every animal (Figure 2). Fetal brain dissections were carried out in the cold, in each case using the tissue from the right hemisphere. A cut was made through the cerebral cortex to obtain the frontal lobes with a second cut just caudal to the infundibulum. The section in between the cuts was flipped over and the right temporal cortex and hippocampus were then removed and separated from each other. A coronal cut was made at the level of the optic chiasm and the caudate was separated from the hypothalamus. The parietal cortex and occipital cortex were dissected and separated from each other and the right occipital cortex was frozen for analysis. The midbrain and brainstem were divided just below the pons and the right half of the brainstem was frozen. All tissue samples were shipped on dry ice by overnight express to Duke University and were stored at $-80^{\circ} \mathrm{C}$ until analyzed. Owing to the small amounts of material available, in some tissues we were able to perform only selected determinations from the set of assays described below. 


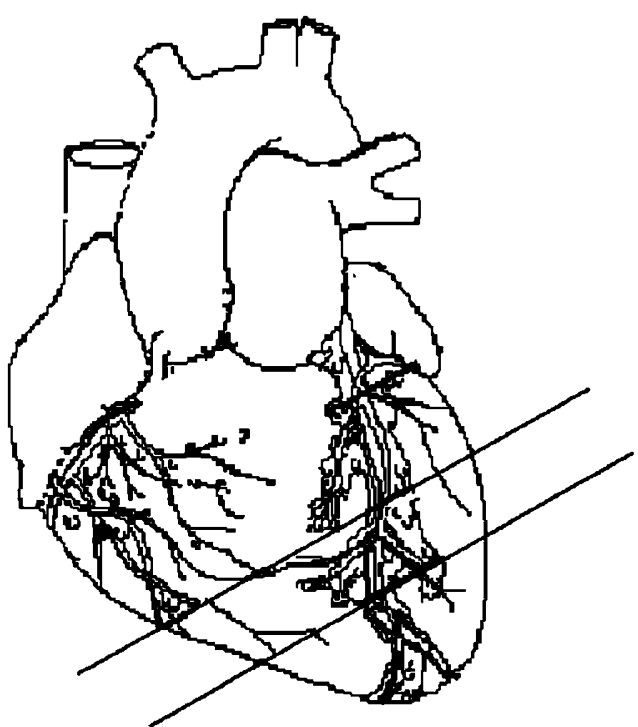

Figure 2 Schematic showing the segment of fetal cardiac left and right ventricle used for analysis, between the indicated cut-lines.

\section{Membrane Preparations}

Tissues were thawed and homogenized (Polytron, Brinkmann Instruments, Westbury, NY, USA) in 20-30 volumes of ice-cold $50 \mathrm{mM}$ Tris- $\mathrm{HCl}$ buffer $(\mathrm{pH} 7.4)$ and where necessary to remove connective tissue, strained through several layers of cheesecloth. Aliquots were withdrawn for the measurements of DNA and total protein. To prepare the cell membrane fraction, the homogenates were sedimented at $40000 \times g$ for $10 \mathrm{~min}$ and the supernatant solution was discarded. The membrane pellet was resuspended (Polytron) in the original volume of buffer, resedimented, and the resultant pellet was resuspended in one-quarter of the original volume of the same buffer, using a smooth glass homogenizer fitted with a Teflon pestle. Aliquots of this resuspension were withdrawn for measurements of ligand binding, and for membrane protein.

The techniques for binding of each of the radioligands have been described in detail previously (Auman et al, 2001; Slotkin et al, 1999, 2002, 2003b; Trauth et al, 1999; Zeiders et al, 1997). Briefly, $\left[{ }^{125} \mathrm{I}\right] \alpha$-bungarotoxin binding was assessed in quadruplicate aliquots of the membrane suspension (two aliquots for total binding and two for nonspecific binding). Each assay contained a final concentration of $1 \mathrm{nM}$ radioligand in a total volume of $250 \mu \mathrm{l}$ of a buffer consisting of $120 \mathrm{mM} \mathrm{NaCl}, 5 \mathrm{mM} \mathrm{KCl}, 2.5 \mathrm{mM} \mathrm{CaCl}_{2}$, $1 \mathrm{mM} \mathrm{MgCl} 2$ and $50 \mathrm{mM}$ Tris (pH 7.4). Incubations were conducted for $120 \mathrm{~min}$ at $25^{\circ} \mathrm{C}$, after which $4 \mathrm{ml}$ of ice-cold buffer were added and the membranes trapped by filtration on glass fiber filters that were presoaked with $0.05 \%$ polyethyleneimine. Labeled membranes were washed three times with $4 \mathrm{ml}$ of buffer and the filters were counted for radioactivity. Nonspecific binding was assessed by displacement with $10 \mu \mathrm{M}$ nicotine. $\left[{ }^{3} \mathrm{H}\right]$ Cytisine binding was evaluated similarly, except that the incubations occurred at $4^{\circ} \mathrm{C}$ for $75 \mathrm{~min}$. To evaluate $\beta \mathrm{AR}$ binding, membrane aliquots were incubated with $\left[{ }^{125} \mathrm{I}\right]$ iodopindolol (final concentration $67 \mathrm{pM}$ ), in $145 \mathrm{mM} \mathrm{NaCl}, 2 \mathrm{mM} \mathrm{MgCl}_{2}$, $1 \mathrm{mM}$ sodium ascorbate and $20 \mathrm{mM}$ Tris ( $\mathrm{pH} 7.5$ ), for $20 \mathrm{~min}$ at room temperature in a total volume of $250 \mu \mathrm{l}$; nonspecific binding was assessed by displacement with $100 \mu \mathrm{M}$ isoproterenol. For $\mathrm{m}_{2} \mathrm{AChR}$ binding, membrane aliquots were diluted in $10 \mathrm{mM}$ sodium-potassium phosphate buffer ( $\mathrm{pH} 7.4)$ and incubated for $60 \mathrm{~min}$ at room temperature, using $1 \mathrm{nM}\left[{ }^{3} \mathrm{H}\right] \mathrm{AFDX} 384$ with or without $1 \mu \mathrm{M}$ atropine to displace specific binding.

Nonspecific binding varied widely according to the radioligand and brain region or tissue. For $\alpha 7 n A C h R s$, values ranged from $60 \%$ in the brainstem to $80 \%$ in cerebrocortical regions, whereas nonspecific binding for the $\alpha 4 \beta 2$ subtype was much lower (20-30\%). The ligands used for $\beta \mathrm{AR}$ and $\mathrm{m}_{2} \mathrm{AChR}$ evaluations showed the lowest proportions of nonspecific binding, $<10 \%$.

\section{Adenylyl Cyclase}

For assessment of AC enzymatic activity, aliquots of the same membrane preparation were incubated for $10 \mathrm{~min}$ (brain regions) or $30 \mathrm{~min}$ (peripheral tissues) at $30^{\circ} \mathrm{C}$ with final concentrations of $100 \mathrm{mM}$ Tris- $\mathrm{HCl}(\mathrm{pH} 7.4), 10 \mathrm{mM}$ theophylline, $1 \mathrm{mM}$ ATP, $2 \mathrm{mM} \mathrm{MgCl}_{2}, 1 \mathrm{mg} / \mathrm{ml}$ bovine serum albumin, and a creatine phosphokinase-ATP-regenerating system consisting of $10 \mathrm{mM}$ sodium phosphocreatine and $8 \mathrm{IU} / \mathrm{ml}$ phosphocreatine kinase, with $10 \mu \mathrm{M}$ GTP in a total volume of $250 \mu \mathrm{l}$. The enzymatic reaction was stopped by placing the samples in a $90-100^{\circ} \mathrm{C}$ water bath for $5 \mathrm{~min}$, followed by sedimentation at $3000 \times g$ for $15 \mathrm{~min}$, and the supernatant solution was assayed for cyclic AMP using radioimmunoassay. Preliminary experiments showed that the enzymatic reaction was linear well beyond the assay period and was linear with membrane protein concentration; concentrations of cofactors were optimal and, in particular, higher concentrations of GTP produced no further augmentation of activity. In addition to measuring basal AC activity, we assessed the response to the direct AC stimulants, forskolin $(100 \mu \mathrm{M})$ and $\mathrm{Mn}^{2+}(10 \mathrm{mM})$, as well as the response to $\beta \mathrm{AR}$ stimulation ( $100 \mu \mathrm{M}$ isoproterenol), or in the caudate, dopamine stimulation $(100 \mu \mathrm{M})$. Effects mediated through muscarinic cholinergic receptors were evaluated with $100 \mu \mathrm{M}$ carbachol in the presence of GTP and forskolin. As $\mathrm{m}_{2} \mathrm{AChRs}$ can evoke inhibition of AC through the inhibitory G-protein, $G_{i}$, the effects of carbachol were evaluated in the presence of forskolin so as to stimulate AC, which makes inhibitory responses more readily detectable (Chow et al, 2000; Garofolo et al, 2002; Slotkin et al, 1999). The chosen concentrations of each stimulant elicit maximal responses, as assessed in earlier studies (Auman et al, 2000, 2001; Garofolo et al, 2002; Zeiders et al, 1997, 1999a).

\section{Macromolecules}

DNA was determined in aliquots of the same original tissue homogenates used for receptor binding, using a modified (Trauth et al, 2000) fluorescent dye-binding method (Labarca and Piagen, 1980). Aliquots were diluted with $10 \mathrm{mM}$ Tris, $0.1 \mathrm{M} \mathrm{NaCl}, 1 \mathrm{mM}$ EDTA (pH 7.4) and sonicated briefly (Virsonic Cell Disrupter, Virtis, Gardiner, NY, USA). Hoechst 33258 was added to a final concentration of $0.1 \mu \mathrm{g} / \mathrm{ml}$. Samples were then read in a spectrofluorometer using an excitation wavelength of $356 \mathrm{~nm}$ and an emission wavelength of $458 \mathrm{~nm}$, and were quantitated using standards of purified DNA. The total concentration of 
tissue proteins was assayed from the original homogenate spectrophotometrically with bicinchoninic acid (Smith et al, 1985); in addition, we assessed the concentration of membrane proteins from the preparations used for radioligand binding.

\section{TBARS}

Lipid peroxidation was evaluated by assessment of thiobarbituric acid-reactive species, conducted similarly to published procedures (Guan et al, 2003). Aliquots of the original tissue homogenate were diluted with $2 \%$ sodium dodecylsulfate, $1 \mathrm{mM}$ diethylenedinitrilotetraacetic acid, and $5 \%$ trichloroacetic acid, followed by addition of two volumes of thiobarbituric acid reagent $(0.45 \% 2$ 2-thiobarbituric acid dissolved in $1 \mathrm{M} \mathrm{NaOH}$, followed by the addition of acetic acid to a final concentration of $12 \%$ ). Samples were incubated for $1 \mathrm{~h}$ at $95^{\circ} \mathrm{C}$, cooled to ambient temperature, sedimented at $3000 \times g$ for $15 \mathrm{~min}$, and the absorbance of the supernatant solution was determined at $532 \mathrm{~nm}$. Standard curves were constructed with known concentrations of malondialdehyde that had been run through the same reaction.

\section{Data Analysis}

To reduce the likelihood of type 1 statistical errors that might result from repeated testing of the data set, we first performed a global analysis of variance (ANOVA) (with logtransformed data because of heterogeneous variance) incorporating all the variables and measures: prenatal treatment, brain region, and the different biomarkers. The latter were treated as repeated measures, since the various assays all originated from the same tissue homogenate in a given animal. This initial test indicated treatment effects that differed among the different biomarkers, so data were then examined separately for each measure, again using a multivariate ANOVA. Where appropriate, this was followed by post hoc evaluations of each treatment group compared to the controls or to each other, using Fisher's Protected Least Significant Difference; however, where treatment effects did not interact with other variables only the main effect was recorded without testing of individual differences. Significance was assumed at the level of $p<0.05$ for main effects; however, for interactions at $p<0.1$, we also examined whether lower-order main effects were detectable after subdivision of the interactive variables (Snedecor and Cochran, 1967).

The study design required two different ways of regarding nicotine and choline treatment variables. To compare the effects $v s$ the controls for nicotine or choline exposure alone, or the combined exposure, the four treatment groups were considered as a one-dimensional factor in the statistical design. To determine whether the effects of nicotine and choline were interactive, the treatment factors were changed to a two-dimensional design. In this formulation, more-than-additive (synergistic) and lessthan-additive effects appear as significant interactions between the two treatment dimensions, whereas simple, additive effects do not show significant interactions.

Data are presented as means and standard errors. To facilitate comparisons across multiple tissues and variables, the effects of each treatment are given as the percentage change from the corresponding control group, but statistical comparisons were made on the original data. For reference, control values appear in Table 1 .

\section{Materials}

Osmotic minipumps were obtained from Durect Corp. (Cupertino, CA, USA). Bacteriostatic water was obtained

Table I Biomarkers in Control Fetuses

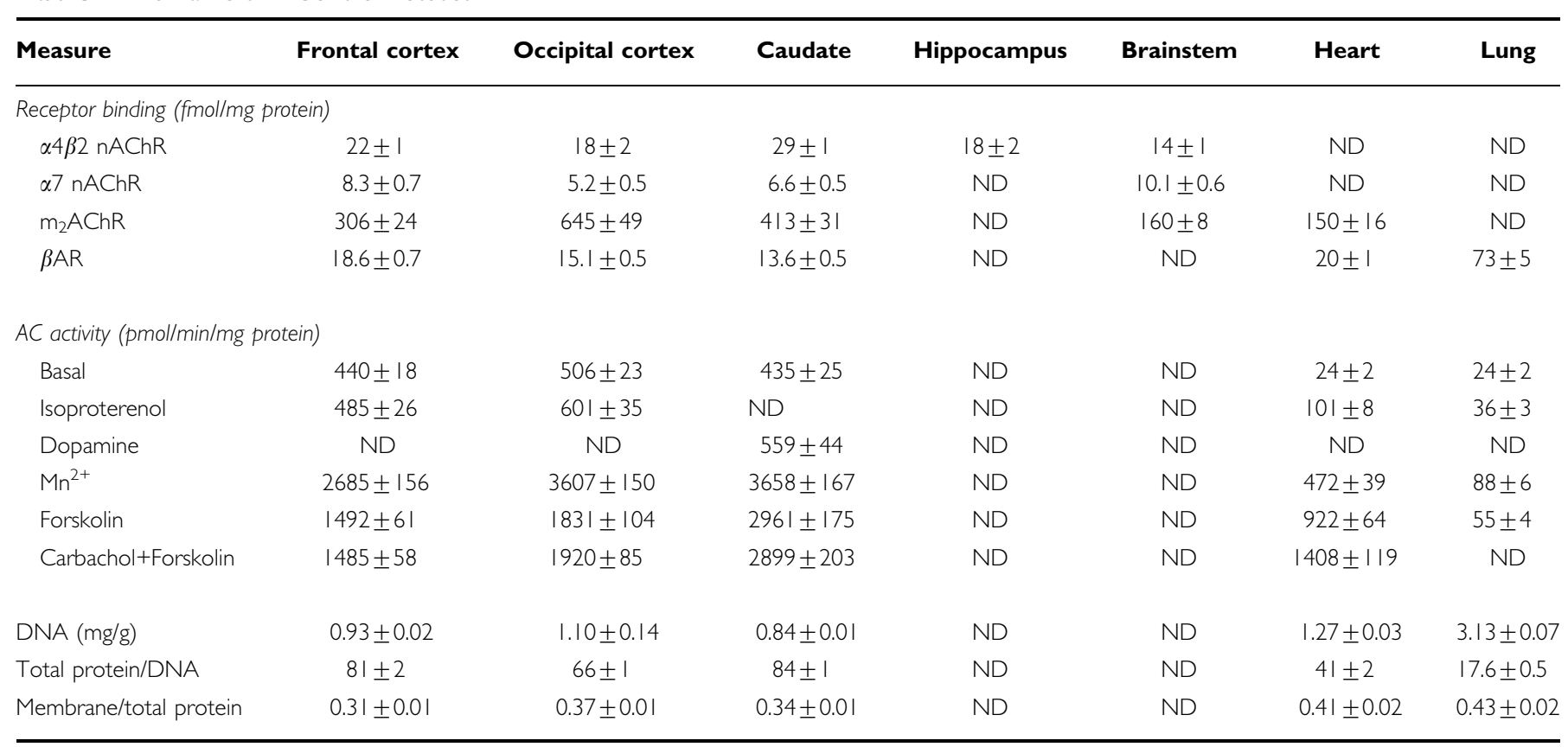

$\mathrm{ND}=$ not done. 
from Abbott Laboratories (N. Chicago, IL, USA). Radioisotopically-labeled compounds came from PerkinElmer Life Sciences (Boston, MA, USA): $\left[{ }^{3} \mathrm{H}\right]$ cytisine (specific activity, $35 \mathrm{Ci} / \mathrm{mmol}$ ), $\left[{ }^{125} \mathrm{I}\right] \alpha$-bungarotoxin (specific activity, $136 \mathrm{Ci} / \mathrm{mmol}$ ), $\left[{ }^{3} \mathrm{H}\right] \mathrm{AFDX} 384$ (specific activity, $133 \mathrm{Ci} /$ $\mathrm{mmol}$ ), and [ $\left.{ }^{125} \mathrm{I}\right]$ iodopindolol (specific activity $2200 \mathrm{Ci} /$ $\mathrm{mmol}$ ). Cyclic AMP radioimmunoassay kits were purchased from Amersham Pharmacia Biotech (Piscataway, NJ, USA). Sigma Chemical Co. (St Louis, MO, USA) was the source for all other reagents.

\section{RESULTS}

Nicotine administration to pregnant monkeys, alone or in combination with dietary supplementation with choline or vitamin $\mathrm{C}$, produced nicotine levels in maternal plasma of about $30 \mathrm{ng} / \mathrm{ml}$, comparable to those associated with maternal smoking in humans or with the use of transdermal nicotine patches (Benowitz et al, 1990; Fredrickson et al, 1995; Isaac and Rand, 1972; Lichtensteiger et al, 1988; Luck et al, 1985; Murrin et al, 1987); cotinine averaged $120 \mathrm{ng} / \mathrm{ml}$. The nicotine concentrations in amniotic fluid were substantially lower, in the range of $10-15 \mathrm{ng} / \mathrm{ml}$, and the cotinine levels were $70-100 \mathrm{ng} / \mathrm{ml}$. Surprisingly, coadministration of either choline or Vitamin C substantially increased the nicotine concentration in the amniotic fluid $(20-25 \mathrm{ng} / \mathrm{ml})$, and cotinine showed a less notable increase $(90-110 \mathrm{ng} / \mathrm{ml})$. The results will be provided in detail in a separate publication containing an analysis of nicotine pharmacokinetics in this model.

In control fetal brain, there were wide regional disparities in the concentrations of neurotransmitter receptors (Table 1). For $\alpha 4 \beta 2 \mathrm{nAChRs,} \mathrm{values} \mathrm{were} \mathrm{highest} \mathrm{in} \mathrm{the}$ caudate and lowest in the brainstem, with intermediate values in the frontal and occipital cortex and in the hippocampus. A very different pattern was evident for the $\alpha 7 n A C h R$ subtype, which showed highest values in the brainstem. The concentrations of $\mathrm{m}_{2} \mathrm{AChRs}$ were much greater than those of nAChRs and followed the rank order, occipital cortex $>$ caudate $>$ frontal cortex $>$ brainstem. In the heart, $\mathrm{m}_{2} \mathrm{AChR}$ values were in the same range as the lowest of the brain regions but in contrast, the concentration of $\beta$ ARs was much higher in peripheral tissues than in any of the brain regions.

Either isoproterenol (frontal cortex, occipital cortex) or dopamine (caudate) evoked significant AC stimulation, as did isoproterenol in the membrane preparations from peripheral tissues (Table $1 ; p<0.0001$ for each region or tissue). However, the degree of stimulation was unrelated to the receptor concentration, as the isoproterenol $\mathrm{AC}$ response was $10 \%$ above basal values in cortical regions, $50 \%$ in the lung, and $300 \%$ in the heart, despite the fact that $\beta$ AR binding was similar in heart and cortical regions, and highest in the lung. This result is in keeping with previous observations that the degree of receptor coupling to downstream signaling elements is the key determinant of the net response (Gao et al, 1998, 1999; Navarro et al, 1991). Similarly, carbachol failed to inhibit AC despite high $\mathrm{m}_{2} \mathrm{AChR}$ concentrations, implying either that there is relatively poor coupling of these receptors to $G_{i}$ in the fetal brain or, alternatively, that stimulation by other mAChR subtypes offsets the inhibitory effect of $\mathrm{m}_{2} \mathrm{AChRs}$ (Gurwitz et al, 1994; Mangels and Gnegy, 1992; Migeon et al, 1995; Olianas and Onali, 1994); in keeping with the latter interpretation, there was significant stimulation by carbachol in the heart $(p<0.0001)$. The direct AC stimulants, forskolin and $\mathrm{Mn}^{2+}$, produced massive responses in all regions and tissues, but again the magnitude was highly tissue-specific: stimulation by forskolin was 40 -fold in the heart but only three- to seven-fold in the lung or brain regions, and stimulation by $\mathrm{Mn}^{2+}$ was 20 -fold in the heart and only four- to eight-fold elsewhere. In addition, AC isoform differences were apparent from the disparities in the response ratio of forskolin/ $\mathrm{Mn}^{2+}$, which was about 2 in the heart but $<1$ in the lung and in brain regions.

Global ANOVA across all treatments and all measurements in the three brain regions for which all parameters could be measured (frontal cortex, occipital cortex, caudate) indicated a main treatment effect $(p<0.0001)$, which differed among the individual measurements and the brain regions $(p<0.0001$ for treatment $\times$ measure, $p<0.08$ for treatment $\times$ region $\times$ measure). Accordingly, we separated the evaluations into separate groups of measurements (receptors, cell signaling, cell development biomarkers, TBARS for lipid peroxidation) and then reexamined the treatment effects separately in each region.

\section{Effects on Receptor Binding}

In the frontal cortex, nicotine treatment upregulated $\alpha 4 \beta 2 \mathrm{nAChR}$ binding without significant effects on $\alpha 7 \mathrm{nAChRs}, \mathrm{m}_{2}$ AchRs, or $\beta$ ARs (Figure $3 \mathrm{a}$ ). Choline (Figure $3 \mathrm{~b}$ ) had about half the effect of nicotine on $\alpha 4 \beta 2 \mathrm{nAChRs}$ and thus the increase did not achieve statistical significance. The combined treatment with

\section{FRONTAL CORTEX}
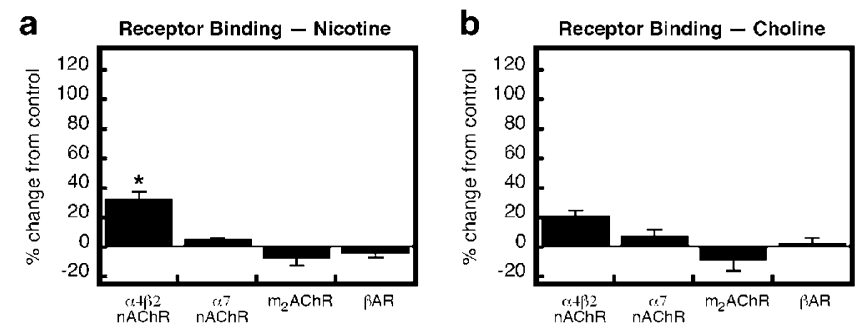

C
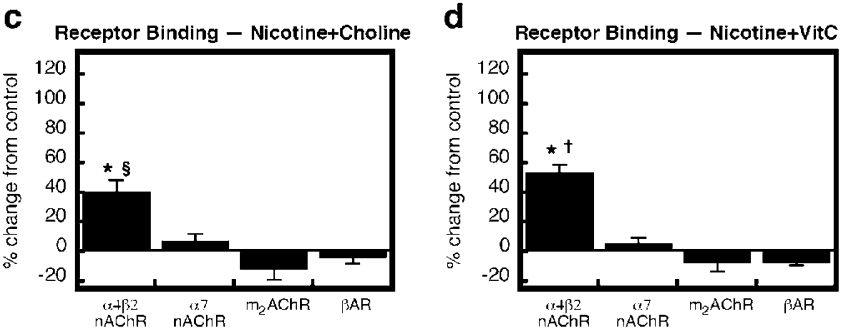

Figure 3 Effects of (a) nicotine, (b) choline, (c) nicotine + choline, and (d) nicotine + Vitamin C (VitC) treatment on receptor binding in the frontal cortex. Data are means and standard errors, presented as the percent change from corresponding control values (Table I). *Significantly different from control values. †Nicotine + VitC group significantly different from nicotine alone. §Nicotine + Choline group significantly different from choline alone. 
nicotine and choline produced $\alpha 4 \beta 2 \mathrm{nAChR}$ upregulation corresponding to the summation of the two separate effects (Figure $3 \mathrm{c}$ ), so that whereas the group receiving combined treatment showed significant elevations over both control and choline groups, there was no significant interaction of nicotine $\times$ choline when the treatments were considered as separate factors in a two-factor ANOVA. Vitamin C supplementation augmented the effect of nicotine, producing significantly greater $\alpha 4 \beta 2 \mathrm{nAChR}$ upregulation than was seen with nicotine alone (Figure $3 \mathrm{~d}$ ).

The effects of nicotine on receptor binding were much greater in the occipital cortex than in the frontal cortex. By itself, nicotine doubled $\alpha 4 \beta 2 \mathrm{nAChR}$ binding and also evoked smaller, but significant increases in the $\alpha 7$ subtype (Figure 4a). Again, choline had about half the effect of nicotine, so that in this region, the upregulation of the $\alpha 4 \beta 2$ receptors was robust (50\% increase) and statistically significant (Figure 4b); the same trend was seen for $\alpha 7 n A C h R s$, namely about half the effect as obtained with nicotine. The combination of nicotine + choline (Figure 4c) produced upregulation of $\alpha 4 \beta 2$ and $\alpha 7 \mathrm{nAChRs} \mathrm{comparable}$ to that seen with nicotine alone, and for the latter, twofactor treatment analysis indicated that the combined effect was less than would have been expected from additive effects of nicotine and choline $(p<0.04$ for the interaction of nicotine $\times$ choline). As in the frontal cortex, Vitamin C supplementation augmented the effect of nicotine on $\mathrm{nAChR}$ binding (Figure 4d); although the difference from nicotine alone did not achieve statistical significance, this was primarily because of the large magnitude of nicotine's effect, and the Vitamin C-induced enhancement was statistically indistinguishable from the significant difference seen in the frontal cortex (no significant treatment $\times$ region interaction). The same 'ceiling effect' may be responsible for limiting the total response to nicotine + choline.
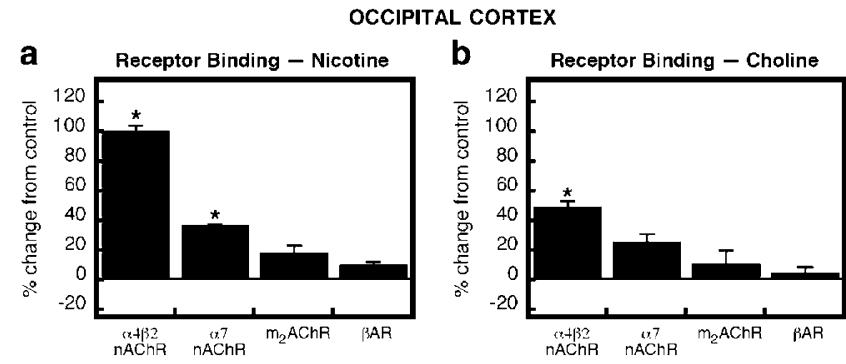

d

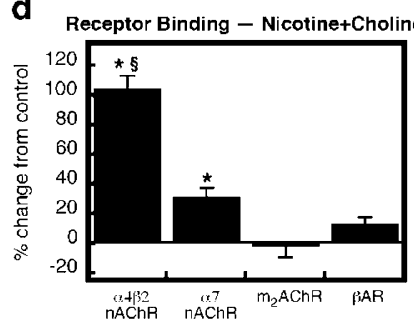

C

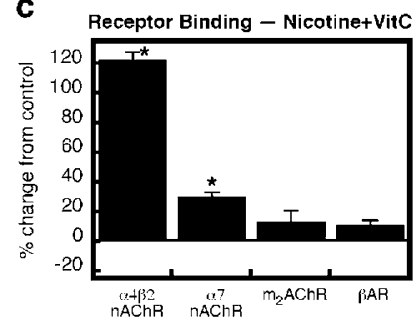

Figure 4 Effects of (a) nicotine, (b) choline, (c) nicotine + choline, and (d) nicotine + Vitamin C (VitC) treatment on receptor binding in the occipital cortex. Data are means and standard errors, presented as the percent change from corresponding control values (Table I). *Significantly different from control values. §Nicotine + Choline group significantly different from choline alone.
The effects of nicotine on receptor binding were least evident in the caudate, where a small $(<20 \%)$ but significant upregulation of $\alpha 4 \beta 2 \mathrm{nAChRs}$ was obtained (Figure 5a). Choline was ineffective (Figure $5 \mathrm{~b}$ ) but nevertheless augmented the effect of nicotine (Figure 5c); again, the interaction was indistinguishable from simple additivity of the effects of the individual agents (no interaction of nicotine $\times$ choline treatment in a two-factor ANOVA). The effect of nicotine was slightly larger when animals received Vitamin C supplementation (Figure 5d), but in light of the small overall effect, the difference from the group receiving nicotine alone was not statistically significant.

The amount of hippocampal tissue available for analysis limited the determinations to the $\alpha 4 \beta 2$ subtype and, similarly, in the brainstem we had to forgo measurement of $\beta$ ARs. Nicotine treatment caused significant elevation of $\alpha 4 \beta 2 \mathrm{nAChRs}$ in both regions (Figure 6a). Choline treatment caused smaller, nonsignificant increases (Figure $6 \mathrm{~b}$ ) but the combination of nicotine and choline elicited much bigger effects than with either agent alone (Figure 6c). As was true in the other regions, dietary supplementation with Vitamin $\mathrm{C}$ augmented the effect of nicotine, significantly increasing $\alpha 4 \beta 2 \mathrm{nAChR}$ binding above the level achieved with nicotine alone (Figure 6d). Vitamin $C$ also augmented the increase in brainstem $m_{2} A C h R s$ so that the effect, although of small magnitude, achieved statistical significance.

Unlike the brain regions, nicotine treatment elicited robust $\mathrm{m}_{2} \mathrm{AChR}$ upregulation in the heart, while at the same time suppressing the expression of $\beta$ ARs (Figure 7a). The latter effect was tissue-selective, as no $\beta A R$ downregulation was seen in the lung. As before, choline elicited about half the effect of nicotine, thus not achieving statistical significance by itself (Figure 7b). However, in this case, choline treatment reduced the effect of nicotine, so that the combined exposure elicited no significant change in cardiac receptor profiles (Figure 7c). Similarly,

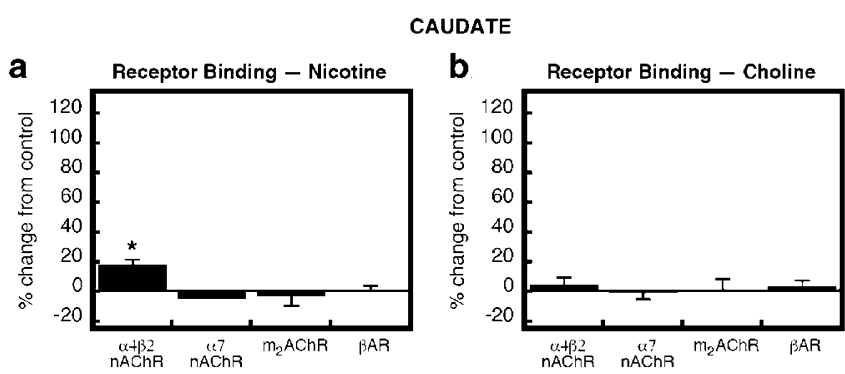

C Receptor Binding - Nicotine+Choline

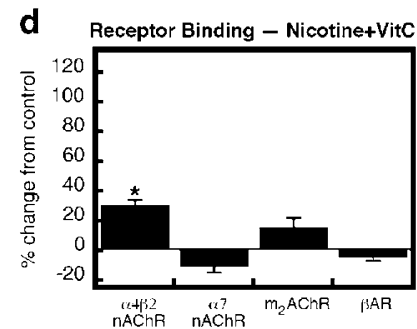

Figure 5 Effects of (a) nicotine, (b) choline, (c) nicotine + choline, and (d) nicotine + Vitamin C (VitC) treatment on receptor binding in the caudate. Data are means and standard errors, presented as the percent change from corresponding control values (Table I). *Significantly different from control values. $§$ Nicotine + Choline group significantly different from choline alone. 
Vitamin C supplementation reduced the net effect of nicotine so that neither of the cardiac receptors showed significant differences from the control group (Figure 7d). At the same time, however, combining nicotine either with choline (Figure 7c) or Vitamin C (Figure 7a) elicited significant reductions in lung $\beta$ ARs.
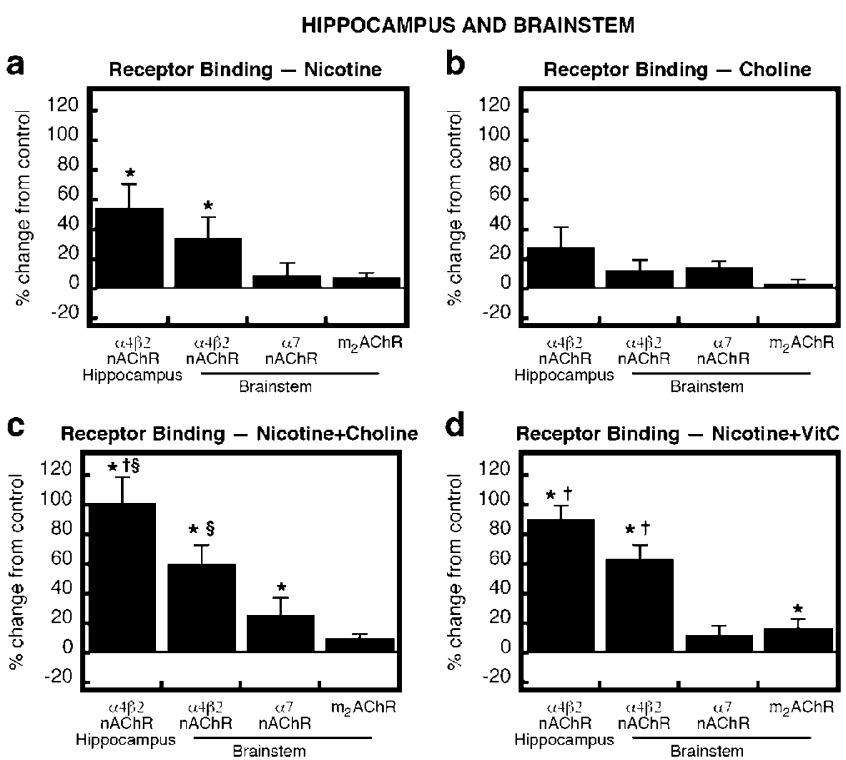

Figure 6 Effects of (a) nicotine, (b) choline, (c) nicotine + choline, and (d) nicotine + Vitamin C (VitC) treatment on receptor binding in the hippocampus and brainstem. Data are means and standard errors, presented as the percent change from corresponding control values (Table I). *Significantly different from control values. †Nicotine + Choline group or Nicotine + VitC group significantly different from nicotine alone. $\S$ Nicotine + Choline group significantly different from choline alone.
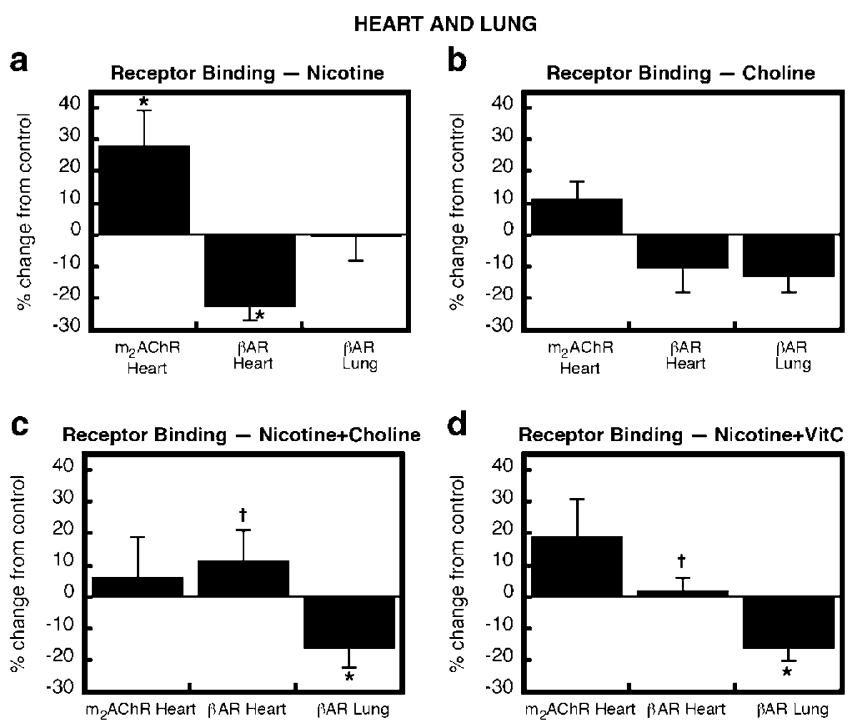

Figure 7 Effects of (a) nicotine, (b) choline, (c) nicotine + choline, and (D) nicotine + Vitamin C (VitC) treatment on receptor binding in the heart and lung. Data are means and standard errors, presented as the percent change from corresponding control values (Table I). *Significantly different from control values. + Nicotine + Choline group or Nicotine + VitC group significantly different from nicotine alone.

\section{Effects on AC Signaling}

Just as was true for receptor binding, there were strong regional disparities in the effects on cell signaling mediated through AC. In the frontal cortex, nicotine elicited little or no change in response to any of the AC stimulants (Figure 8a), but choline produced robust activation of the responses (Figure $8 \mathrm{~b}$ ). The pattern reflected heterologous activation of signaling proteins downstream from the receptors, as there was parallel activation of basal AC, receptor-mediated responses, and responses to direct $\mathrm{AC}$ stimulants. Cotreatment with nicotine and choline produced an effect midway between those of nicotine and choline alone, with smaller, but still significant, enhancement of AC responses (Figure 8c). On the other hand, Vitamin $\mathrm{C}$ supplementation augmented the effect above that seen with nicotine alone (Figure $8 \mathrm{~d}$ ).

Unlike the situation in the frontal cortex, none of the treatments elicited a significant alteration in cell signaling in the occipital cortex (Figure 9). In the caudate, nicotine (Figure 10a) or choline (Figure 10b) alone elicited slight increases in $\mathrm{AC}$ responses, but only the choline effect on the dopamine response achieved statistical significance. In contrast, combined exposure to both nicotine and choline elicited robust activation of all AC responses (Figure 10c), representing the summation of the two individual effects (no interaction of nicotine $\times$ choline treatment in a twofactor ANOVA). Vitamin C supplementation augmented the effect of nicotine, producing $20-30 \%$ elevations in the AC responses (Figure 10d). In all cases, the effects on $\mathrm{AC}$ were heterologous, with parallel changes in basal AC, receptormediated responses, and responses to direct AC stimulants

\section{FRONTAL CORTEX}
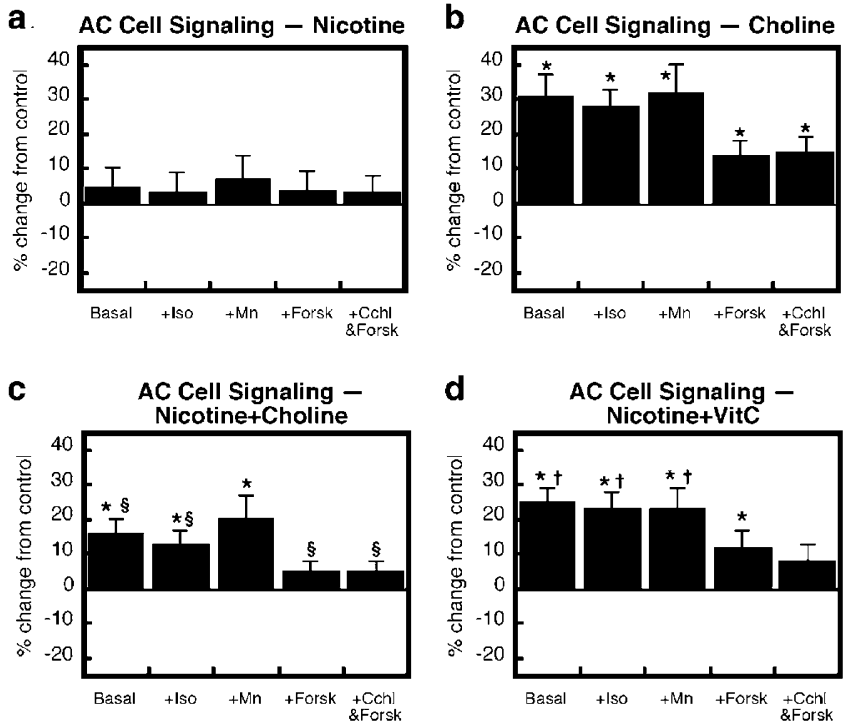

Figure 8 Effects of (a) nicotine, (b) choline, (c) nicotine + choline, and (d) nicotine + Vitamin C (VitC) treatment on AC signaling in the frontal cortex. Data are means and standard errors, presented as the percent change from corresponding control values (Table I). *Significantly different from control values. †Nicotine $+V i t C$ group significantly different from nicotine alone. §Nicotine + Choline group significantly different from choline alone. Abbreviations: Iso =isoproterenol, Forsk=forskolin, Cchl= carbachol. 


\section{OCCIPITAL CORTEX}
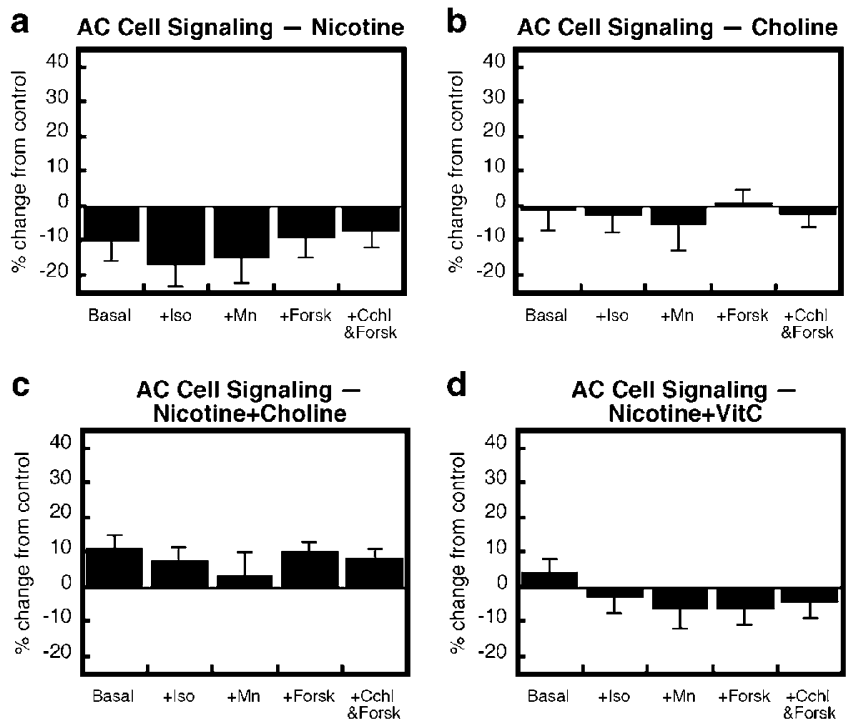

Figure 9 Effects of (a) nicotine, (b) choline, (c) nicotine + choline, and (d) nicotine + Vitamin C (VitC) treatment on AC signaling in the occipital cortex. Data are means and standard errors, presented as the percent change from corresponding control values (Table I). None of the effects is statistically significant. Abbreviations: Iso $=$ isoproterenol, Forsk = forskolin, $\mathrm{Cchl}=$ carbachol

\section{CAUDATE}
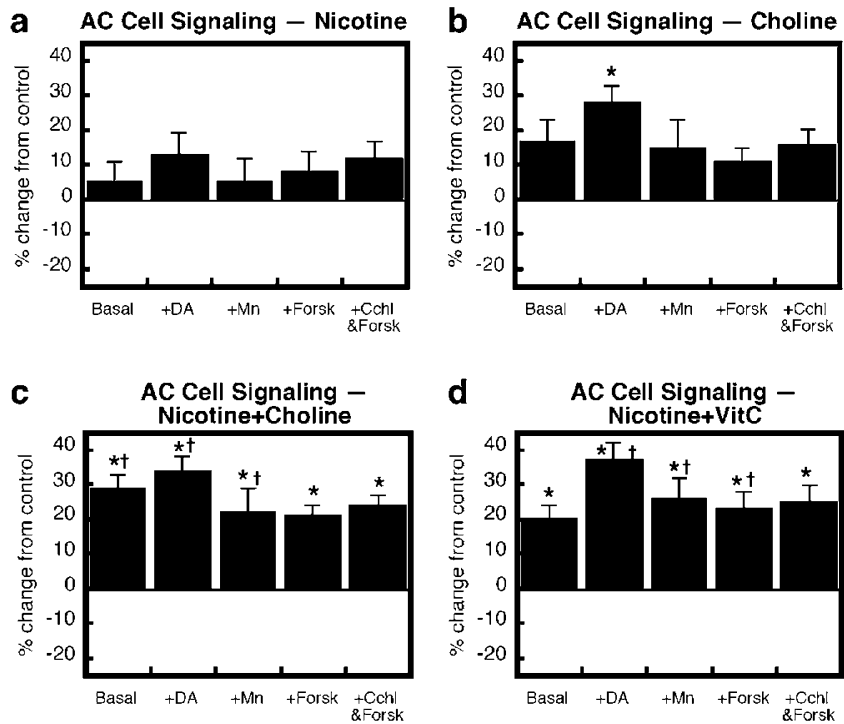

Figure 10 Effects of (a) nicotine, (b) choline, (c) nicotine + choline, and (d) nicotine + Vitamin C (VitC) treatment on AC signaling in the caudate. Data are means and standard errors, presented as the percent change from corresponding control values (Table I). *Significantly different from control values. †Nicotine + Choline group or Nicotine + VitC group significantly different from nicotine alone. Abbreviations: $D A=$ dopamine, Forsk $=$ forsforskolin, Cchl = carbachol.

(main effects of treatment without significant treatment $\times$ measure interactions).

As was true for the brain regions, nicotine administration by itself had only minor effects on cell signaling in the heart and lung (Figure 11a); similarly, choline alone evoked little or no change (Figure 11b). However, the combined
HEART AND LUNG
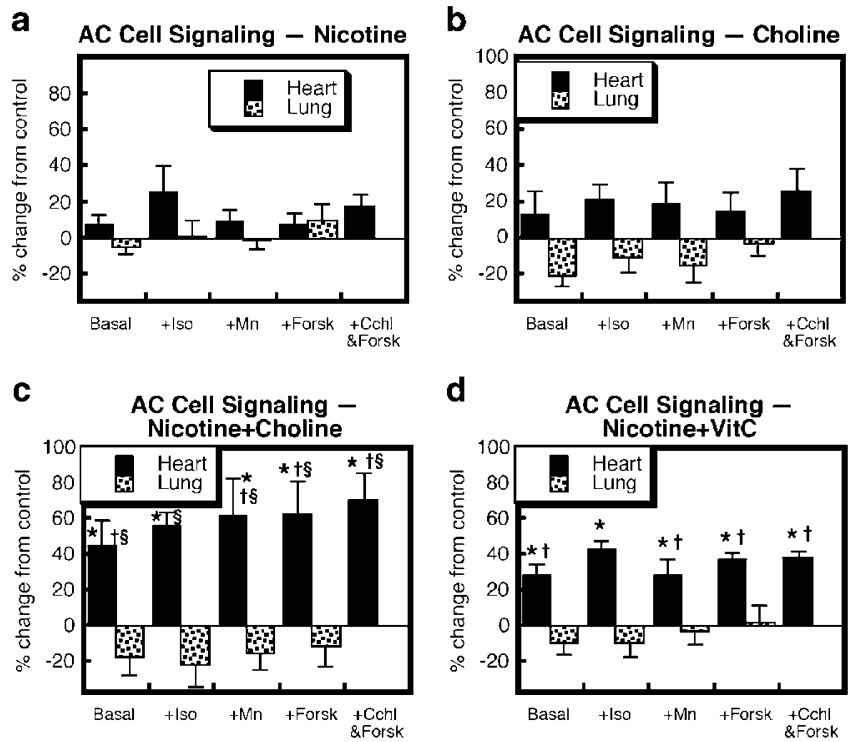

Figure I I Effects of (a) nicotine, (b) choline, (c) nicotine + choline, and (d) nicotine + Vitamin C (VitC) treatment on AC signaling in the heart and lung. Data are means and standard errors, presented as the percent change from corresponding control values (Table I). *Significantly different from control values. †Nicotine + Choline group or Nicotine + VitC group significantly different from nicotine alone. §Nicotine + Choline group significantly different from choline alone. Abbreviations: Iso = isoproterenol, roterenol, Forsk $=$ forskolin, $\mathrm{Cchl}=$ carbachol

treatment with nicotine + choline elicited massive, heterologous enhancement of all AC signaling parameters in the heart, while leaving signaling in the lung largely unaffected (Figure 11c). Vitamin $\mathrm{C}$ also heterologously enhanced the ability of nicotine to stimulate cardiac AC signaling (Figure 11d).

\section{Effects on Cell Development Biomarkers}

In the frontal cortex, either nicotine (Figure 12a) or choline (Figure 12b) alone elicited small, nonsignificant changes in DNA concentration and in the ratios of total protein to DNA and membrane to total protein. However, with combined treatment (Figure 12c), significant differences emerged, characterized by a decline in the index of cell size (total protein/DNA) and a corresponding rise in the relative membrane surface area (membrane/total protein). These effects represented the summation of the nonsignificant alterations wrought by nicotine and choline alone, as there was no significant nicotine $\times$ choline interaction in a twofactor analysis of treatment effects. When nicotine was combined with Vitamin C supplementation, there was a substantially larger decrement in the total protein/DNA ratio (Figure 12d).

In the occipital cortex, nicotine exposure had an adverse effect on the membrane/total protein ratio, while leaving indices of cell number and cell size unchanged (Figure 13a). By itself, choline had a similar, albeit lesser effect (Figure $13 \mathrm{~b})$ and in this case, choline coadministration lessened the effect of nicotine (Figure 13c). Two-factor analysis of the combined treatment indicated a significant nicotine $x$ 
choline interaction $(p<0.01)$, indicating that the effect was significantly smaller than that predicted by the summation of the two separate effects. Vitamin C had no further effect when superimposed on the actions of nicotine alone (Figure 13d).

Nicotine exerted profound effects on cell development biomarkers in the caudate, evoking about a $10 \%$ deficit in the number of cells (reduced DNA concentration), with a corresponding rise in the total protein/DNA ratio
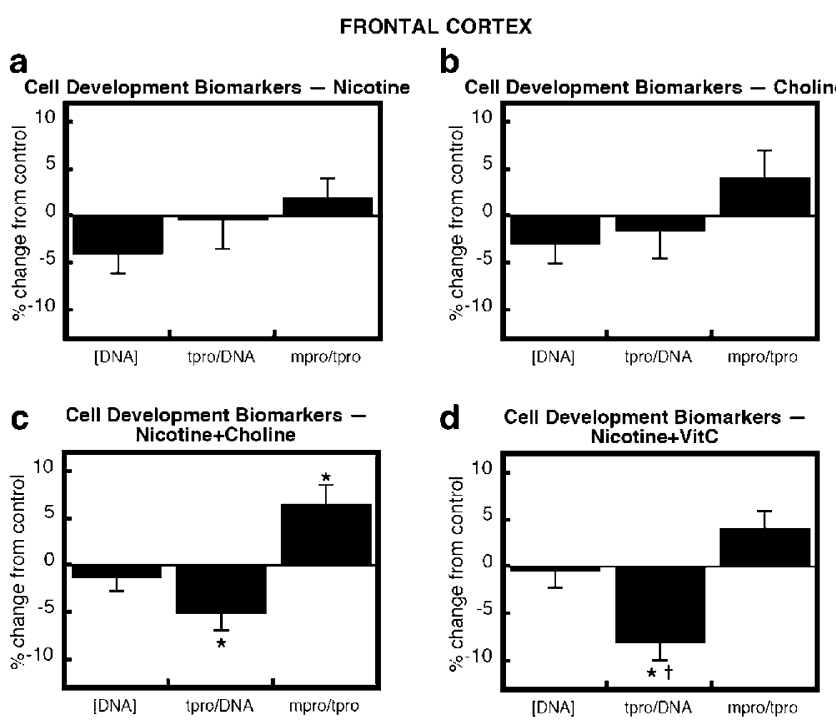

Figure 12 Effects of (a) nicotine, (b) choline, (c) nicotine + choline, and (d) nicotine + Vitamin C (VitC) treatment on cell development biomarkers in the frontal cortex. Data are means and standard errors, presented as the percent change from corresponding control values (Table I). *Significantly different from control values. $†$ Nicotine $+V i t C$ group significantly different from nicotine alone. Abbreviations: tpro=total protein, $\mathrm{mpro}=$ membrane protein.

OCCIPITAL CORTEX

a b
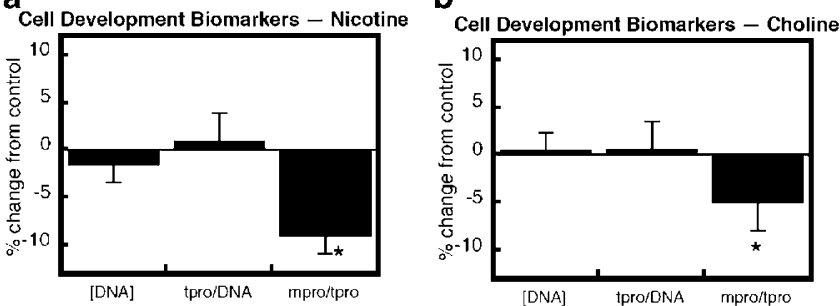

Cell Development Biomarkers -
Nicotine+Choline

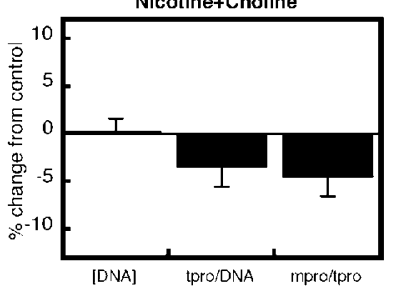

d Cell Development Biomarkers -

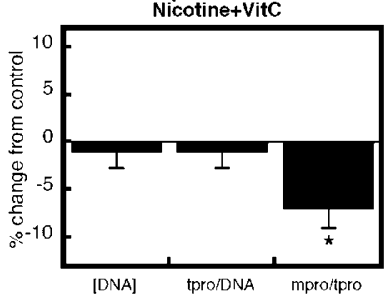

Figure 13 Effects of (a) nicotine, (b) choline, (c) nicotine + choline, and (d) nicotine + Vitamin C (VitC) treatment on cell development biomarkers in the occipital cortex. Data are means and standard errors, presented as the percent change from corresponding control values (Table I). *Significantly different from control values. Abbreviations: tpro =total protein; $\mathrm{mpro}=$ membrane protein
(Figure 14a). In contrast, choline alone had little or no effect (Figure 14b) but, when combined with nicotine administration, it completely prevented the adverse effect of nicotine (Figure 14c). Similarly, Vitamin C supplementation protected the caudate from the nicotine-induced deficits (Figure 14d). In the heart and lung, there were no significant alterations of any of the treatments, but high variability of

CAUDATE

a

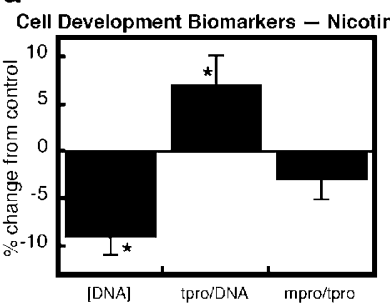

b

Cell Development Biomarkers - Choline
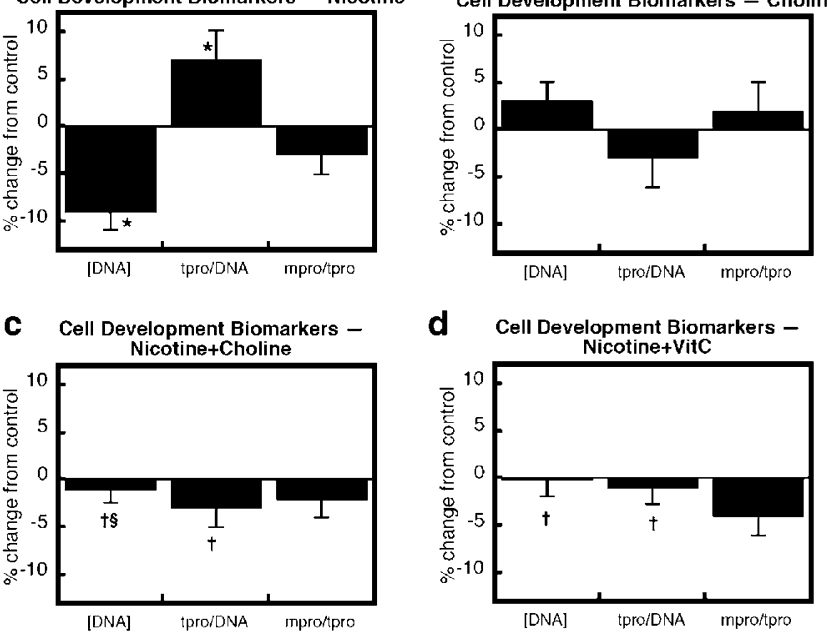

d Cell Development Biomarkers -

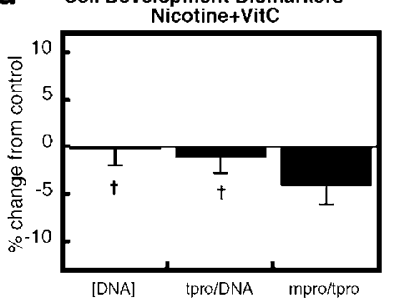

Figure 14 Effects of (a) nicotine, (b) choline, (c) nicotine + choline, and (d) nicotine + Vitamin C (VitC) treatment on cell development biomarkers in the caudate. Data are means and standard errors, presented as the percent change from corresponding control values (Table I). *Significantly different from control values. †Nicotine + Choline group or Nicotine + VitC group significantly different from nicotine alone. §Nicotine + Choline group significantly different from choline alone. Abbreviations: tpro = total protein; $\mathrm{mpro}=$ membrane protein.

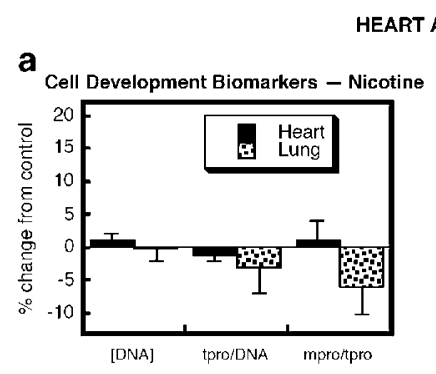

ND LUNG

b
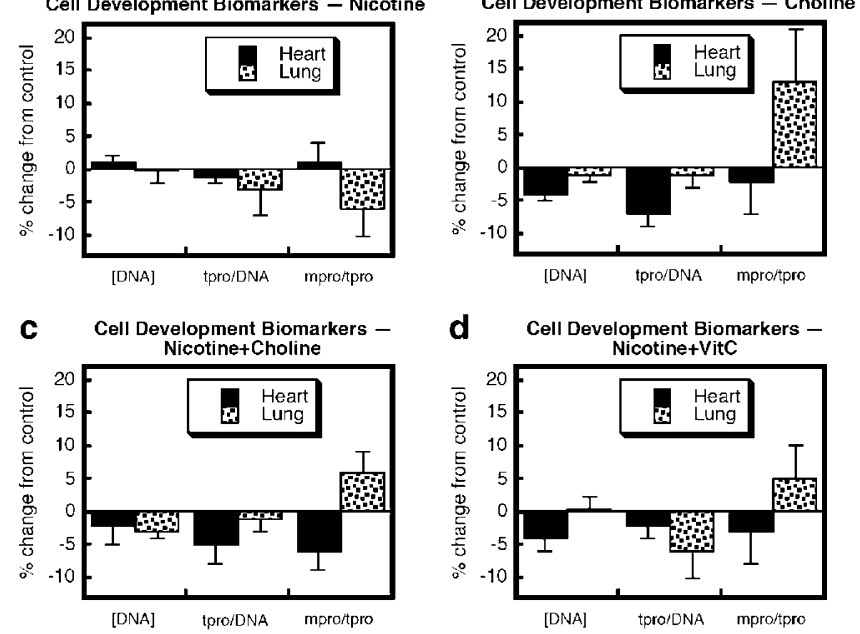

Figure I5 Effects of (a) nicotine, (b) choline, (c) nicotine + choline, and (D) nicotine + Vitamin C (VitC) treatment on cell development biomarkers in the heart and lung. Data are means and standard errors, presented as the percent change from corresponding control values (Table I). None of the differences is statistically significant. Abbreviations: tpro=total protein; mpro $=$ membrane protein 
some of the measures precluded making conclusions about biologic mechanisms from the negative findings (Figure 15); indeed, many of the nonsignificant changes were of the same magnitude as the significant alterations seen in the brain regions. Accordingly, we relied on multivariate analysis rather than individual effects, that is, looking for abnormal 'patterns' of values across the three measures. Using that approach, the decrease in cardiac values in animals given choline or nicotine + choline was significant $(p<0.05$ and $<0.04$, respectively). In the lung, the small reductions caused by nicotine achieved significance when grouped together $(p<0.05)$ and the effect of choline was distinguishably opposite $(p<0.006$ comparing nicotine and choline to each other), primarily reflecting the differences in membrane/total protein. In combination, nicotine + choline gave values midway between the two individual effects in the lung. It should be noted that mature cardiac cells can be multinucleated so that DNA assessments are unreliable in determining the actual number of cells; however, fetal myocytes generally do not show multinucleation (Soonpaa et al, 1996).

\section{Effects on TBARS}

We did not observe any treatment-related effects on lipid peroxidation as evaluated by TBARS (Table 2). However, there were highly significant differences among the brain regions and peripheral tissues, indicating that treatment effects would have been detectable if present. For the brain regions, the values were much higher in the caudate than in the cortical regions, in agreement with the recognized, greater susceptibility of this dopamine-rich region to the production of oxidative species (Junn and Mouradian, 2001; Karen et al, 2001).

\section{DISCUSSION}

The results of this study indicate that maternal nicotine administration in primates, at concentrations commensurate with cigarette smoking in humans, elicits the hallmark changes of nicotine-induced fetal brain damage that have been noted previously in rodent models (Levin and Slotkin, 1998; Slotkin, 1992, 1998, 1999, 2004). Nicotine exposure evoked significant increments in $\alpha 4 \beta 2 \mathrm{nAChRs}$ in all regions, verifying that sufficient nicotine reached the fetal brain to evoke chronic nicotinic stimulation of the target cells. Indeed, the degree of upregulation was similar to that seen in comparable brain regions of adult smokers (Breese et al, 1997) or in rodent models of prenatal nicotine exposure (Levin and Slotkin, 1998; Slotkin, 1992, 1998, 1999, 2004). Nevertheless, there were strong regional disparities in the response, with the greatest increase seen in the occipital cortex, less in the hippocampus, brainstem and frontal cortex, and least in the caudate, suggesting differential susceptibility to nicotine-induced cellular effects. That conclusion was reinforced first by the finding that only the occipital cortex showed upregulation of $\alpha 7 \mathrm{nAChRs}$, the receptor subpopulation specifically associated with responses to cell injury and neuritic development (Chan and Quik, 1993; Quik et al, 1994; Verbois et al, 2002), and this same region showed a deficit in the membrane/total protein ratio, a biomarker for neuronal projections. Nicotine also had an adverse effect on cell number, as indicated by a significant overall decrement in the DNA concentration. By far the greatest effect was in the caudate, where the loss of cells was accompanied by cell enlargement (increased total protein/DNA ratio), which may either be compensatory or could also represent perikaryal swelling as a cytotoxic reaction. However, the caudate was the region showing the least upregulation of nAChRs, implying a different underlying mechanism for cell damage and loss in this region. As will be discussed below, the protective action of Vitamin $\mathrm{C}$ in the caudate implies that the additional, adverse cellular effects in this region are likely to involve its high susceptibility to oxidative stress.

In contrast to the robust and significant effects of nicotine on nAChRs and cell injury biomarkers, there was little or no effect on cell signaling parameters or on expression of CNS $\beta A R s$ or $m_{2} A C h R s$. However, studies in rodent models suggest that these emerge at subsequent, postnatal stages (Slotkin et al, 1990, 1992) and thus are not likely to be detected in the late gestational period sampled here. In contrast, in the periphery we found a significant decrement in cardiac $\beta$ ARs and elevation in $\mathrm{m}_{2} \mathrm{AChRs}$, effects that also have been found with prenatal nicotine exposure in rats (Navarro et al, 1990; Slotkin et al, 1999). The former effect was specific to the heart rather than representing global interference with $\beta \mathrm{AR}$ expression, since $\beta \mathrm{ARs}$ were unaffected in the CNS or lung. Similarly, the receptor effects were not secondary to more generalized alterations in cardiac cell development or signaling parameters, which were largely unaffected by nicotine exposure. Studies in rodents show changes in cardiac responsiveness that parallel the alterations in $\beta$ ARs and $\mathrm{m}_{2} \mathrm{AChRs}$ (Navarro et al, 1990; Slotkin et al, 1997, 1999), and therefore the shifts seen here are likely to be of key importance. $\beta$ ARs provide

Table 2 Effects on TBARS

\begin{tabular}{|c|c|c|c|c|c|c|}
\hline Treatment & Frontal cortex & Occipital cortex & Caudate & Heart & Lung & Placenta \\
\hline Control & $25 \pm 2$ & $47 \pm 1$ & $232 \pm 16$ & $42 \pm 1$ & $42 \pm 1$ & $13 \mid \pm 10$ \\
\hline Nicotine & $25 \pm 1$ & $43 \pm 3$ & $220 \pm 10$ & $43 \pm 1$ & $4 I \pm 3$ & $131 \pm 6$ \\
\hline Nicotine+Choline & $24 \pm 1$ & $48 \pm 2$ & $256 \pm 18$ & $45 \pm 1$ & $45 \pm 2$ & $125 \pm 6$ \\
\hline Nicotine+Vitamin C & $25 \pm 1$ & $46 \pm 4$ & $248 \pm 14$ & $43 \pm 1$ & $43 \pm 4$ & $133 \pm 11$ \\
\hline
\end{tabular}

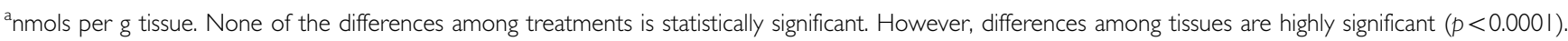


stimulatory input and $\mathrm{m}_{2} \mathrm{AChR}$ inhibitory input, so that the imbalance evoked by nicotine would render the heart more susceptible to arrest during challenges such as hypoxia (Slotkin et al, 1995, 1997). The fetal environment is hypoxic, and hypoxia is ineluctable during labor (Hanson et al, 1993; Lagercrantz and Slotkin, 1986; Southall et al, 1993; Valdes-Dapena, 1981). Accordingly, the fact that nicotine exposure upsets the careful balance of cardiac cellular excitation and inhibition is likely to contribute to the association of maternal smoking with increased perinatal morbidity and mortality (DiFranza and Lew, 1995), findings that have their parallel in previous results with rats (Slotkin et al, 1995, 1997, 1999; Tolson et al, 1995).

Choline supplementation is mandated for infant formulas marketed in the US and choline promotes membrane formation necessary for brain development and plasticity, while protecting the brain from injurious effects of neurotoxicants such as ethanol (Meck and Williams, 1999; Montoya et al, 2000; Thomas et al, 2000; Williams et al, 1998). On the other hand, choline supplementation also augments cholinergic effects (Mike et al, 2000; Wurtman, 1988), which in the developing brain might contribute to nicotine-like actions that produce neurobehavioral defects (Bell and Lundberg, 1985; Bell and Slotkin, 1985; Bell et al, 1986a, b; Levin and Slotkin, 1998; Slotkin, 1992, 1999, 2004). Accordingly, we assessed the effects of choline alone and in combination with nicotine. By itself, choline administration elicited nicotine-like effects, albeit at a lower level than those achieved with nicotine. Upregulation of $\alpha 4 \beta 2$ and $\alpha 7 n A C h R s$ was significant across all the brain regions (ANOVA main effects, $p<0.0007$ and $<0.04$, respectively), with the greatest response in the occipital cortex, just as found for nicotine. As was true for nicotine, choline elicited a shortfall in the membrane/total protein ratio in the occipital cortex, suggestive of impaired neurite formation, a result in keeping with nicotinic actions predominating over any promotional effects on membrane formation. In the caudate, choline did not evoke the shortfall in cell numbers that were seen with nicotine, an expected result given the likelihood of a different mechanism (oxidative stress) for that particular effect of nicotine.

However, the best illustration of the dual actions of choline is provided by the results for cell signaling. In the frontal cortex and caudate, choline evoked robust increases in all aspects of AC signaling, indicative of induction of the signaling proteins themselves, as would be expected from augmented membrane formation. In contrast, this effect was notably absent in the occipital cortex, the region showing nicotine-like $\mathrm{nAChR}$ upregulation and cell damage. Accordingly, it might be expected that, whereas choline could protect the developing brain from the adverse effects of nicotine, it may also augment cholinergic effects contributing to nicotine-induced damage. Indeed, with the combination of nicotine + choline we found higher $\mathrm{nAChR}$ upregulation in all brain regions as compared to either treatment alone, representing the additive cholinergic effects of the two treatments. Neuroprotection was evident from the reduced effect on cell damage biomarkers in the occipital cortex and caudate, where the effects of choline offset the adverse changes elicited by nicotine. At the same time, though, the frontal cortex showed additive deficits in the index of cell size: although neither nicotine nor choline produced significant decrements alone, the combined treatment elicited a significant reduction in total protein/ DNA and a concomitant rise in membrane/total protein that would connote an increase in the surface/volume ratio associated with smaller cells. Effects of the combination of nicotine + choline similarly gave a regionally selective pattern of effects on cell signaling. In the frontal cortex, the promotional effect of choline was lessened by the combination with nicotine whereas effects in the caudate appeared to be additive. The most dramatic interaction for effects on signaling was seen in the heart, where the combined treatment elicited massive heterologous stimulation of all inputs to AC activity, effects far exceeding the summation of the modest changes seen with either agent alone. The effect on cardiac signaling was associated with a complete reversal of nicotine's adverse effects on the balance of $\beta$ ARs and $\mathrm{m}_{2} \mathrm{AChRs}$. Nevertheless, considering that the AC pathway is shared by numerous neuronal and hormonal inputs, a global increase in activity may be associated with abnormal responsiveness to trophic inputs that are vital to cardiac cell development, and future work will need to address the issue of whether these changes have otherwise unanticipated drawbacks. In the same vein, the effect of combined nicotine + choline treatment worsened the deficits in lung $\beta$ ARs, so that the two individually nonsignificant effects achieved significance for the combined treatment.

Nicotine has the ability to both evoke and prevent oxidative stress, depending on its concentration and the neurodevelopmental stage at which exposure occurs (Guan et al, 2003). Accordingly, we hypothesized that Vitamin $C$ supplementation might offset oxidative-related adverse effects of nicotine on the developing brain. To our surprise, Vitamin $\mathrm{C}$ enhanced $\mathrm{nAChR}$ upregulation in response to nicotine. Furthermore, in brain regions and tissues where nicotine evoked nonsignificant increases in AC signaling (frontal cortex, caudate, heart), the addition of Vitamin C rendered all these changes robust and significant. For the cell damage biomarkers, rather than providing uniform protection from the adverse effects of nicotine, Vitamin $\mathrm{C}$ supplementation had mixed actions. In the frontal cortex, combined treatment worsened the deficits in total protein/ DNA, and in the occipital cortex, Vitamin $\mathrm{C}$ failed to protect the cells from the nicotine-induced reduction in membrane/ total protein. However, there was significant protection from cell damage in the caudate, where Vitamin $\mathrm{C}$ completely prevented the cell loss evoked by nicotine. One possible explanation for dichotomous effects of Vitamin $\mathrm{C}$ is that in high doses, it can actually be prooxidant (Song et al, 1999), so that regional targeting might depend on the underlying oxidative status of each region. The caudate is especially susceptible to oxidative damage in part because of the high concentration of dopamine, an oxidative neurotransmitter that is released by nicotine (Blum et al, 2001; El-Bizri and Clarke, 1994; Karen et al, 2001; Rowell, 1995), so the protective effect of Vitamin C in this region is likely to represent the different underlying mechanism of neural cell damage from those operating in the frontal or occipital cortex, where nicotine stimulation and upregulation of nAChRs were the predominant events. When we examined each region for lipid peroxidation, we found far higher values in the caudate, in keeping with its prooxidant 
status. However, nicotine administration did not elevate TBARS, nor did choline or Vitamin C supplementation affect the values. A strict assignment of a role for oxidative stress or protection by antioxidant effects is thus problematic; since we evaluated TBARS at only one time point, it is conceivable that the oxidative damage occurs earlier and is thus not evident as lipid peroxidation products at the time of sampling.

The effects of Vitamin $C$ supplementation on peripheral tissues were also decidedly mixed. Vitamin $C$ prevented the decline in cardiac $\beta$ ARs evoked by nicotine but did not alter the upregulation of $\mathrm{m}_{2} \mathrm{AChRs}$ and worsened the decline in $\beta$ ARs in the lung. Thus, regardless of the underlying mechanism, the point remains that Vitamin $\mathrm{C}$, like choline, exerts dichotomous actions, and rather than producing uniform protection, may worsen some of the adverse effects of nicotine.

Unexpectedly, we found that nicotine in the amniotic fluid was significantly increased by supplementation with either choline or Vitamin C. Although our results do not explicitly identify the mechanisms responsible for these differences, a number of inferences can be drawn from the relative changes in nicotine and cotinine. First, the fact that maternal levels were unchanged suggests that the supplements do not alter maternal distribution, metabolism or clearance of nicotine or cotinine, but rather that the effects are exerted in the fetal compartment itself. In the amniotic fluid, nicotine levels were augmented by the supplements more than were those for cotinine, a result in keeping with impaired nicotine clearance and/or catabolism in the fetal compartment. The mechanisms underlying these effects are thus worth exploring, since higher concentrations of nicotine and cotinine in the fetal environment may be one of the major reasons for the worsening of many of the effects of nicotine on brain development. Similarly, the infusion model used here is an appropriate simulation of continuous nicotine delivery as is typical of transdermal nicotine patches, and although smokers tend to maintain a steady-state nicotine plasma level, these are likely to decay somewhat overnight when smoking ceases. A recent study showed that continuous nicotine delivery in rodents results in more than a two-fold higher fetal nicotine brain level as compared to maternal blood (Sarasin et al, 2003). Accordingly, future studies should address the impact of different modes of nicotine delivery, with and without dietary supplements, on the actual levels of nicotine achieved in fetal brain.

In conclusion, our results show that prenatal nicotine exposure in a primate model, at maternal nicotine levels commensurate with human smoking during pregnancy, elicits changes in indices of cholinergic function, cell signaling, and cell damage, indicative of disrupted brain cell development. These effects show discrete regional selectivities that, in part, reflect differences in nAChR responses to prolonged nicotine administration, but that also are influenced by the disparate neurotransmitter and cell populations within each region. Although choline or Vitamin C supplementation protects the developing brain from some aspects of nicotine-induced neurotoxicity, other aspects are worsened, reflecting both pharmacodynamic and pharmacokinetic parameters that augment the cellular responses to nicotine as well as the concentration of nicotine in the fetal compartment. One critical conclusion from our results is that dietary supplements that may be beneficial in normative populations, or that may protect the developing brain from a defined set of neurotoxicants, may contribute to worsened outcomes when the fetus is exposed to nicotine as in the case of maternal smoking. Future studies need to consider the concept that smoking may thus create vulnerable subpopulations in whom dietary supplements evoke untoward effects in combination with nicotine exposure.

\section{ACKNOWLEDGEMENTS}

Supported by a grant from Philip Morris USA, and NIH RR00163, HD/HL37131, and ES07031. We thank Dr John Fanton, Darla Jacob and the staff of the ONPRC Division of Animal Resources for assistance with animal surgeries and timed pregnancies.

\section{REFERENCES}

Auman JT, Seidler FJ, Slotkin TA (2000). Neonatal chlorpyrifos exposure targets multiple proteins governing the hepatic adenylyl cyclase signaling cascade: implications for neurotoxicity. Dev Brain Res 121: 19-27.

Auman JT, Seidler FJ, Slotkin TA (2001). Regulation of fetal cardiac and hepatic $\beta$-adrenoceptors and adenylyl cyclase signaling: terbutaline effects. Am J Physiol 281: R1079-R1089.

Bell JM, Lundberg PK (1985). Effects of a commercial soy lecithin preparation on development of sensorimotor behavior and brain biochemistry in the rat. Dev Psychobiol 18: 59-66.

Bell JM, Slotkin TA (1985). Perinatal dietary supplementation with a commercial soy lecithin preparation: effects on behavior and brain biochemistry in the developing rat. Dev Psychobiol 18: 383-394.

Bell JM, Whitmore WL, Barnes G, Seidler FJ, Slotkin TA (1986a). Perinatal dietary exposure to soy lecithin: altered sensitivity to central cholinergic stimulation. Int J Dev Neurosci 4: 497-501.

Bell JM, Whitmore WL, Cowdery T, Slotkin TA (1986b). Perinatal dietary supplementation with a soy lecithin preparation: effects on development of central catecholaminergic neurotransmitter systems. Brain Res Bull 17: 189-195.

Bell JM, Whitmore WL, Queen KL, Orband-Miller L, Slotkin TA (1987). Biochemical determinants of growth sparing during neonatal nutritional deprivation or enhancement: ornithine decarboxylase, polyamines, and macromolecules in brain regions and heart. Pediatr Res 22: 599-604.

Benowitz NL, Dempsey DA, Goldenberg RL, Hughes JR, DolanMullen P, Ogburn PL et al (2000). The use of pharmacotherapies for smoking cessation during pregnancy. Tobacco Control 9: iii91-iii94.

Benowitz NL, Porchet H, Jacob III P (1990). Pharmacokinetics, metabolism, and pharmacodynamics of nicotine. In: Wonnacott S, Russell MAH, Stolerman IP (eds). Nicotine Psychopharmacology. Oxford Press: New York. pp 112-157.

Blum D, Torch S, Lambeng N, Nissou M, Benabid AL, Sadoul R et al (2001). Molecular pathways involved in the neurotoxicity of 6-OHDA, dopamine and MPTP: contribution to the apoptotic theory in Parkinson's disease. Prog Neurobiol 65: 135-172.

Breese CR, Marks MJ, Logel J, Adams CE, Sullivan B, Collins AC et al (1997). Effect of smoking history on $\left[{ }^{3} \mathrm{H}\right]$ nicotine binding in human postmortem brain. J Pharmacol Exp Ther 282: 7-13.

Chan J, Quik M (1993). A role for the nicotinic $\alpha$-bungarotoxin receptor in neurite outgrowth in PC12 cells. Neuroscience 56: $441-451$. 
Choi WS, Ronnekleiv OK (1996). Effects of in utero cocaine exposure on the expression of mRNAs encoding the dopamine transporter and the D1, D2 and D5 dopamine receptor subtypes in fetal rhesus monkey. Dev Brain Res 96: 249-260.

Chow FA, Seidler FJ, McCook EC, Slotkin TA (2000). Adolescent nicotine exposure alters cardiac autonomic responsiveness: $\beta$ adrenergic and $\mathrm{m} 2$-muscarinic receptors and their linkage to adenylyl cyclase. Brain Res 878: 119-126.

DiFranza JR, Lew RA (1995). Effect of maternal cigarette smoking on pregnancy complications and Sudden Infant Death Syndrome. J Fam Pract 40: 385-394.

El-Bizri H, Clarke PBS (1994). Blockade of nicotinic receptormediated release of dopamine from striatal synaptosomes by chlorisondamine administered in vivo. Br J Pharmacol 111: 414418.

Ernst M, Moolchan ET, Robinson ML (2001). Behavioral and neural consequences of prenatal exposure to nicotine. J Am Acad Child Adolesc Psychiatry 40: 630-641.

Fang YA, Ronnekleiv OK (1999). Cocaine upregulates the dopamine transporter in fetal rhesus monkey brain. J Neurosci 19: $8966-8978$

Flores CM, Rogers SW, Pabreza LA, Wolfe BB, Kellar KJ (1992). A subtype of nicotinic cholinergic receptor in rat brain is composed of $\alpha 4$ and $\beta 2$ subunits and is upregulated by chronic nicotine treatment. Mol Pharmacol 41: 31-37.

Frank DA, Augustyn M, Knight WG, Pell T, Zuckerman B (2001). Growth, development, and behavior in early childhood following prenatal cocaine exposure: a systematic review. J Am Med Assoc 285: 1613-1625.

Fredrickson PA, Hurt RD, Lee GM, Wingender L, Croghan IT, Lauger $G$ et al (1995). High dose transdermal nicotine therapy for heavy smokers: safety, tolerability and measurement of nicotine and cotinine levels. Psychopharmacology 122: 215-222.

Gao MH, Lai NC, Roth DM, Zhou JY, Zhu J, Anzai T et al (1999). Adenylyl cyclase increases responsiveness to catecholamine stimulation in transgenic mice. Circulation 99: 1618-1622.

Gao MH, Ping PP, Post S, Insel PA, Tang RY, Hammond HK (1998). Increased expression of adenylylcyclase type VI proportionately increases $\beta$-adrenergic receptor-stimulated production of cAMP in neonatal rat cardiac myocytes. Proc Natl Acad Sci 95: 1038-1043.

Garofolo MC, Seidler FJ, Auman JT, Slotkin TA (2002). Adrenergic modulation of muscarinic cholinergic receptor expression and function in the developing heart. Am J Physiol 282: R1356-R1363.

Guan ZZ, Yu WF, Nordberg A (2003). Dual effects of nicotine on oxidative stress and neuroprotection in PC12 cells. Neurochem Int 43: 243-249.

Gurwitz D, Haring R, Heldman E, Fraser CM, Manor D, Fisher A (1994). Discrete activation of transduction pathways associated with acetylcholine $\mathrm{m} 1$ receptor by several muscarinic ligands. Eur J Pharmacol 267: 21-31.

Hanson M, Calder N, Watanabe T, Kumar P (1993). The drive to breathe and sudden infant death syndrome. Acta Pcediatr Suppl 389: 47-49.

Happe HK, Peters JL, Bergman DA, Murrin LC (1994). Localization of nicotinic cholinergic receptors in rat brain: autoradiographic studies with $\left[{ }^{3} \mathrm{H}\right]$ cytisine. Neuroscience 62: 929-944.

Isaac PF, Rand MJ (1972). Cigarette smoking and plasma levels of nicotine. Nature 236: 308-310.

Jacob P, Wilson M, Benowitz NL (1981). Improved gas chromatographic method for the determination of nicotine and cotinine in biologic fluids. J Chromatogn 222: 61-70.

Jacob P, Yu L, Wilson M, Benowitz NL (1991). Selected ion monitoring method for determination of nicotine, cotinine, and deuterium-labeled analogs: absence of an isotope effect in the clearance of (S)-Nicotine- $3^{\prime}, 3^{\prime}-\mathrm{D} 2$ in humans. Biol Mass Spectrom 20: 247-252.
Junn E, Mouradian MM (2001). Apoptotic signaling in dopamineinduced cell death: the role of oxidative stress, p38 mitogenactivated protein kinase, cytochrome $c$ and caspases. $J$ Neurochem 78: 374-383.

Karen DJ, Li W, Harp PR, Gillette JS, Bloomquist JR (2001). Striatal dopaminergic pathways as a target for the insecticides permethrin and chlorpyrifos. Neurotoxicology 22: 811-817.

Labarca C, Piagen K (1980). A simple, rapid, and sensitive DNA assay procedure. Anal Biochem 102: 344-352.

Lagercrantz H, Slotkin TA (1986). The 'stress' of being born. Sci Am 254: 100-107.

Lauder JM, Schambra UB (1999). Morphogenetic roles of acetylcholine. Environ Health Perspect 107(Suppl 1): 65-69.

Levin ED, Slotkin TA (1998). Developmental neurotoxicity of nicotine. In: Slikker W, Chang LW (eds). Handbook of Developmental Neurotoxicology. Academic Press: San Diego. pp 587-615.

Levitt P, Harvey JA, Friedman E, Simansky K, Murphy EH (1997). New evidence for neurotransmitter influences on brain development. Trends Neurosci 20: 269-274.

Lichtensteiger W, Ribary U, Schlumpf M, Odermatt B, Widmer HR (1988). Prenatal adverse effects of nicotine on the developing brain. Prog Brain Res 73: 137-157.

Lidow MS, Song ZM (2001). Effect of cocaine on cell proliferation in the cerebral wall of monkey fetuses. Cerebr Cortex 11: 545551.

Luck W, Nau H, Hansen R, Steldinger R (1985). Extent of nicotine and cotinine transfer to the human fetus, placenta and amniotic fluid of smoking mothers. Dev Pharmacol Ther 8: 384-395.

Mangels LA, Gnegy ME (1992). Cyclic AMP accumulation alters calmodulin localization in SK-N-SH human neuroblastoma cells. Mol Brain Res 12: 103-110.

Meck WH, Williams CL (1999). Choline supplementation during prenatal development reduces proactive interference in spacial memory. Dev Brain Res 118: 51-59.

Migeon JC, Thomas SL, Nathanson NM (1995). Differential coupling of $\mathrm{m} 2$ and $\mathrm{m} 4$ muscarinic receptors to inhibition of adenylyl cyclase by $\mathrm{G}_{\mathrm{i} \alpha}$ and $\mathrm{G}_{\mathrm{o} \alpha}$. J Biol Chem 270: 16070-16074.

Mike A, Castro NG, Albuquerque EX (2000). Choline and acetylcholine have similar kinetic properties of activation and desensitization on the $\alpha 7$ nicotinic receptors in rat hippocampal neurons. Brain Res 882: 155-168.

Montoya DAC, White AM, Williams CL, Blusztajn JK, Meck WH, Swartzwelder HS (2000). Prenatal choline exposure alters hippocampal responsiveness to cholinergic stimulation in adulthood. Dev Brain Res 123: 25-32.

Murrin LC, Ferrer JR, Wanyun Z, Haley NJ (1987). Nicotine administration to rats: methodological considerations. Life Sci 40: $1699-1708$

Navarro HA, Kudlacz EM, Slotkin TA (1991). Control of adenylate cyclase activity in developing rat heart and liver: effects of prenatal exposure to terbutaline or dexamethasone. Biol Neonate 60: $127-136$.

Navarro HA, Mills E, Seidler FJ, Baker FE, Lappi SE, Tayyeb MI et al (1990). Prenatal nicotine exposure impairs $\beta$-adrenergic function: persistent chronotropic subsensitivity despite recovery from deficits in receptor binding. Brain Res Bull 25: 233-237.

Olianas MC, Onali P (1994). Activation of opioid and muscarinic receptors stimulates basal adenylyl cyclase but inhibits $\mathrm{Ca}^{2+}$ calmodulin- and forskolin-stimulated enzyme activities in rat olfactory bulb. J Neurochem 63: 161-168.

Qiao D, Seidler FJ, Abreu-Villaça Y, Tate CA, Cousins MM, Slotkin TA (2004). Chlorpyrifos exposure during neurulation: cholinergic synaptic dysfunction and cellular alterations in brain regions at adolescence and adulthood. Dev Brain Res 148: 43-52.

Qiao D, Seidler FJ, Padilla S, Slotkin TA (2002). Developmental neurotoxicity of chlorpyrifos: what is the vulnerable period? Environ Health Perspect 110: 1097-1103. 
Qiao D, Seidler FJ, Tate CA, Cousins MM, Slotkin TA (2003). Fetal chlorpyrifos exposure: adverse effects on brain cell development and cholinergic biomarkers emerge postnatally and continue into adolescence and adulthood. Environ Health Perspect 111: 536-544.

Quik M, Chan J, Patrick J (1994). Bungarotoxin blocks the nicotinic receptor mediated increase in cell number in a neuroendocrine cell line. Brain Res 655: 161-167.

Rowell PP (1995). Nanomolar concentrations of nicotine increase the release of $\left[{ }^{3} \mathrm{H}\right]$ dopamine from rat striatal synaptosomes. Neurosci Lett 189: 171-175.

Sarasin A, Schlumpf M, Müller M, Fleischmann I, Lauber ME, Lichtensteiger W (2003). Adrenal-mediated rather than direct effects of nicotine as a basis of altered sex steroid synthesis in fetal and neonatal rat. Reprod Toxicol 17: 153-162.

Sekhon HS, Jia YB, Raab R, Kuryatov A, Pankow JF, Whitsett JA et al (1999). Prenatal nicotine increases pulmonary $\alpha 7$ nicotinic receptor expression and alters fetal lung development in monkeys. J Clin Invest 103: 637-647.

Sekhon HS, Keller JA, Benowitz NL, Spindel ER (2001). Prenatal nicotine exposure alters pulmonary function in newborn rhesus monkeys. Am J Respir Crit Care Med 164: 989-994.

Shaywitz AJ, Greenberg ME (1999). CREB: a stimulus-induced transcription factor activated by a diverse array of extracellular signals. Annu Rev Biochem 68: 821-861.

Slotkin TA (1992). Prenatal exposure to nicotine: what can we learn from animal models?. In: Zagon IS, Slotkin TA (eds). Maternal Substance Abuse and the Developing Nervous System. Academic Press: San Diego. pp 97-124.

Slotkin TA (1998). Fetal nicotine or cocaine exposure: which one is worse? J Pharmacol Exp Ther 285: 931-945.

Slotkin TA (1999). Developmental cholinotoxicants: nicotine and chlorpyrifos. Environ Health Perspect 107(Suppl 1): 71-80.

Slotkin TA (2004). Cholinergic systems in brain development and disruption by neurotoxicants: nicotine, environmental tobacco smoke, organophosphates. Toxicol Appl Pharmacol 198: $132-151$

Slotkin TA, Auman JT, Seidler FJ (2003a). Ontogenesis of $\beta$ adrenoceptor signaling: implications for perinatal physiology and for fetal effects of tocolytic drugs. J Pharmacol Exp Ther 306: $1-7$.

Slotkin TA, Epps TA, Stenger ML, Sawyer KJ, Seidler FJ (1999). Cholinergic receptors in heart and brainstem of rats exposed to nicotine during development: implications for hypoxia tolerance and perinatal mortality. Dev Brain Res 113: 1-12.

Slotkin TA, Freibaum BD, Tate CA, Thillai I, Ferguson SA, Cada $\mathrm{AM}$ et al (2003b). Long-lasting CNS effects of a short-term chemical knockout of ornithine decarboxylase during development: nicotinic cholinergic receptor upregulation and subtle macromolecular changes in adulthood. Brain Res 981: 118-125.

Slotkin TA, Lappi SE, McCook EC, Lorber BA, Seidler FJ (1995). Loss of neonatal hypoxia tolerance after prenatal nicotine exposure: implications for Sudden Infant Death Syndrome. Brain Res Bull 38: 69-75.

Slotkin TA, McCook EC, Lappi SE, Seidler FJ (1992). Altered development of basal and forskolin-stimulated adenylate cyclase activity in brain regions of rats exposed to nicotine prenatally. Dev Brain Res 68: 233-239.

Slotkin TA, Navarro HA, McCook EC, Seidler FJ (1990). Fetal nicotine exposure produces postnatal up-regulation of adenylate cyclase activity in peripheral tissues. Life Sci 47: 1561-1567.

Slotkin TA, Persons D, Slepetis RJ, Taylor D, Bartolome J (1984). Control of nucleic acid and protein synthesis in developing brain, kidney, and heart of the neonatal rat: effects of $\alpha$ difluoromethylornithine, a specific, irreversible inhibitor of ornithine decarboxylase. Teratology 30: 211-224.

Slotkin TA, Pinkerton KE, Auman JT, Qiao D, Seidler FJ (2002). Perinatal exposure to environmental tobacco smoke upregulates nicotinic cholinergic receptors in monkey brain. Dev Brain Res 133: $175-179$.

Slotkin TA, Saleh JL, McCook EC, Seidler FJ (1997). Impaired cardiac function during postnatal hypoxia in rats exposed to nicotine prenatally: implications for perinatal morbidity and mortality, and for Sudden Infant Death Syndrome. Teratology 55: $177-184$

Smith PK, Krohn RI, Hermanson GT, Mallia AK, Gartner FH, Provenzano MD et al (1985). Measurement of protein using bicinchoninic acid. Anal Biochem 150: 76-85.

Snedecor GW, Cochran WG (1967). Statistical Methods. Iowa State University Press: Ames, Iowa. pp 593.

Song JH, Shin SH, Ross GM (1999). Prooxidant effects of ascorbate in rat brain slices. J Neurosci Res 58: 328-336.

Soonpaa MH, Kim KK, Pajak L, Franklin M, Field LJ (1996). Cardiomyocyte DNA synthesis and binucleation during murine development. Am J Physiol 40: H2183-H2189.

Southall DP, Noyes JP, Poets CF, Samuels MP (1993). Mechanisms for hypoxæmic episodes in infancy and early childhood. Acta Paediatr Suppl 389: 60-62.

Stachowiak EK, Fang X, Myers J, Dunham S, Stachowiak MK (2003). cAMP-Induced differentiation of human neuronal progenitor cells is mediated by nuclear fibroblast growth factor receptor-1 (FGFR1). J Neurochem 84: 1296-1312.

Thai L, Galluzzo JM, McCook EC, Seidler FJ, Slotkin TA (1996). Atypical regulation of hepatic adenylyl cyclase and adrenergic receptors during a critical developmental period: agonists evoke supersensitivity accompanied by failure of receptor downregulation. Pediatr Res 39: 697-707.

Thomas JD, La Fiette MH, Quinn VRE, Riley EP (2000). Neonatal choline supplementation ameliorates the effects of prenatal alcohol exposure on a discrimination learning task in rats. Neurotoxicol Teratol 22: 703-711.

Tolson CM, Seidler FJ, McCook EC, Slotkin TA (1995). Does concurrent or prior nicotine exposure interact with neonatal hypoxia to produce cardiac cell damage? Teratology 52: 298-305.

Trauth JA, Seidler FJ, McCook EC, Slotkin TA (1999). Adolescent nicotine exposure causes persistent upregulation of nicotinic cholinergic receptors in rat brain regions. Brain Res 851: 9-19.

Trauth JA, Seidler FJ, Slotkin TA (2000). An animal model of adolescent nicotine exposure: effects on gene expression and macromolecular constituents in rat brain regions. Brain Res 867: 29-39.

Valdes-Dapena MA (1981). Sudden infant death syndrome: a review of the medical literature. DHHS Publication HAS, Vol 815271, pp 1-18.

Verbois SL, Scheff SW, Pauly JR (2002). Time-dependent changes in rat brain cholinergic receptor expression after experimental brain injury. J Neurotrauma 19: 1569-1585.

Wakschlag LS, Pickett KE, Cook E, Benowitz NL, Leventhal BL (2002). Maternal smoking during pregnancy and severe antisocial behavior in offspring: a review. Am J Public Health 92: 966-974.

Weiss ER, Maness P, Lauder JM (1998). Why do neurotransmitters act like growth factors? Perspect Dev Neurobiol 5: 323-335.

Weitzman M, Byrd RS, Aligne CA, Moss M (2002). The effects of tobacco exposure on children's behavioral and cognitive functioning: implications for clinical and public health policy and future research. Neurotoxicol Teratol 24: 397-406.

Whitaker-Azmitia PM (1991). Role of serotonin and other neurotransmitter receptors in brain development: basis for developmental pharmacology. Pharmacol Rev 43: 553-561.

Whiting P, Lindstrom J (1987). Purification and characterization of a nicotinic acetylcholine receptor from rat brain. Proc Natl Acad Sci 84: 595-599.

Whiting PR, Lindstrom J (1988). Characterization of bovine and human neuronal nicotinic acetylcholine receptors using monoclonal antibodies. J Neurosci 8: 3395-3404. 
Williams CL, Meck WH, Heyer DD, Loy R (1998). Hypertrophy of basal forebrain neurons and enhanced visuospatial memory in perinatally choline-supplemented rats. Brain Res 794: 225-238.

Winick M, Noble A (1965). Quantitative changes in DNA, RNA and protein during prenatal and postnatal growth in the rat. Dev Biol 12: 451-466.

Wurtman RJ (1988). Effects of their nutrient precursors on the synthesis and release of serotonin, the catecholamines, and acetylcholine: implications for behavioral disorders. Clin $\mathrm{Neu}$ ropharmacol 11: S187-S193.

Yanai J, Vatury O, Slotkin TA (2002). Cell signaling as a target and underlying mechanism for neurobehavioral teratogenesis. Ann NY Acad Sci 965: 473-478.
Zeiders JL, Seidler FJ, Iaccarino G, Koch WJ, Slotkin TA (1999a). Ontogeny of cardiac $\beta$-adrenoceptor desensitization mechanisms: agonist treatment enhances receptor/G-protein transduction rather than eliciting uncoupling. J Mol Cell Cardiol 31: 413423.

Zeiders JL, Seidler FJ, Slotkin TA (1997). Ontogeny of regulatory mechanisms for $\beta$-adrenoceptor control of rat cardiac adenylyl cyclase: targeting of G-proteins and the cyclase catalytic subunit. J Mol Cell Cardiol 29: 603-615.

Zeiders JL, Seidler FJ, Slotkin TA (1999b). Agonist-induced sensitization of $\beta$-adrenoceptor signaling in neonatal rat heart: expression and catalytic activity of adenylyl cyclase. J Pharmacol Exp Ther 291: 503-510. 